\title{
Role of apolipoprotein E in neurodegenerative diseases
}

\author{
This article was published in the following Dove Press journal: \\ Neuropsychiatric Disease and Treatment \\ 16 July 2015 \\ Number of times this article has been viewed
}

\author{
Vo Van Giau' \\ Eva Bagyinszky' \\ Seong Soo A An' \\ SangYun Kim² \\ 'Department of Bionano Technology, \\ Gachon Medical Research Institute, \\ Gachon University, Seongnam, South \\ Korea; ${ }^{2}$ Department of Neurology, \\ Seoul National University College of \\ Medicine in Seoul National Bundang \\ Hospital, Seoul, South Korea
}

\begin{abstract}
Apolipoprotein E (APOE) is a lipid-transport protein abundantly expressed in most neurons in the central nervous system. APOE-dependent alterations of the endocytic pathway can affect different functions. APOE binds to cell-surface receptors to deliver lipids and to the hydrophobic amyloid- $\beta$ peptide, regulating amyloid- $\beta$ aggregations and clearances in the brain. Several APOE isoforms with major structural differences were discovered and shown to influence the brain lipid transport, glucose metabolism, neuronal signaling, neuroinflammation, and mitochondrial function. This review will summarize the updated research progress on APOE functions and its role in Alzheimer's disease, Parkinson's disease, cardiovascular diseases, multiple sclerosis, type 2 diabetes mellitus, Type III hyperlipoproteinemia, vascular dementia, and ischemic stroke. Understanding the mutations in APOE, their structural properties, and their isoforms is important to determine its role in various diseases and to advance the development of therapeutic strategies. Targeting APOE may be a potential approach for diagnosis, risk assessment, prevention, and treatment of various neurodegenerative and cardiovascular diseases in humans.
\end{abstract}

Keywords: apolipoprotein E, pathogenesis, diseases

\section{Introduction}

The apolipoprotein E (APOE) gene is located on chromosome 19 and encodes a glycoprotein that is 299 amino acids long. ${ }^{1}$ It is synthesized in various tissues in the body including the liver, brain, and skin and in macrophages. ${ }^{2}$ In the blood, APOE protein could interact with lipids, resulting in lipoproteins, including very-low-density lipoproteins (VLDL). Several major APOE isoforms can be distinguished: E2, E3, and E4. Six phenotypes were observed as a result of two single nucleotide polymorphisms (SNPs) at amino acid positions 112 and 158. The amino acid changes could alter the protein charge and stability, inducing distinct physiological functions.

APOE plays multiple roles in the regulation of lipid and lipoprotein levels in the

Correspondence: Seong Soo A An Department of Bionano Technology, Gachon Medical Research Institute, Gachon University 1342 Sungnamdaero, Sujung-gu, Seongnam-si, Gyeonggi-do 46I-70I, South Korea

Tel +82 31 7508755

Email seongaan@gachon.ac.kr

SangYun Kim

Department of Neurology, Seoul National University College of Medicine, Seoul National University Bundang Hospital, 173 Gumiro 82, Bundang-gu, Seongnam-si, Gyeonggi-do 463-707, South Korea

Tel +82 3I 7877462

Email neuroksy@snu.ac.kr blood. APOE serves as a ligand for members of low-density lipoprotein (LDL) receptor in the liver. APOE is also involved in the formation of chylomicrons and VLDL and affects the activity of other lipid metabolism-associated proteins and enzymes, such as hepatic lipase and lipoprotein lipase. Emerging study has shown that APOE and APOE isoform functions may extend beyond lipid metabolism to include maintenance of normal brain function. ${ }^{3}$ In this review, we discuss the biological functions of human APOE and its role in Alzheimer's disease (AD), Parkinson's disease (PD), cardiovascular diseases (CVD), multiple sclerosis (MS), type 2 diabetes mellitus (T2DM), vascular dementia (VD), and ischemic (occlusive) stroke (IS). Targeting APOE may be a potential approach for diagnosis, risk assessment, prevention, and treatment of diseases in humans. family and is involved in the removal of lipoproteins from the circulation for excretion 


\section{Importance of APOE APOE functions}

Peripheral system

APOE is a 299 amino acid plasma glycoprotein associated with LDL, VLDL, and high-density lipoproteins (HDL). ${ }^{4}$ Several functions of APOE were identified in the human body. In the plasma, APOE will associate with most lipoproteins. APOE is an integral component of chylomicrons, VLDL, and HDL in the peripheral system (Table 1). It operates as part of an anchoring mechanism that aids the transport of triglyceride, phospholipid, cholesteryl esters, and cholesterol into cells by mediating the binding and internalization of these lipoprotein particles. ${ }^{132}$ APOE has a strong affinity for and is the main ligand for members of low-density lipoprotein receptor (LDLR) family, located on liver and other tissues. This super family includes the LDLR, LDLR-related protein 1 (LRP1), VLDL receptor, and APOE receptor 2. APOE interaction with LDLR mediates the removal of APOE-containing lipoproteins and modulates the homeostasis of lipids in the peripheral system.

In humans, there are three major isoforms of APOE, which are associated with lipoproteins in the plasma, and absorption of APOE-containing lipoprotein complexes by LDL receptors through lipid metabolism has important implications in diseases (Figure 1) ${ }^{5,6}$ Clinical studies have shown that APOE4 is associated with higher plasma total cholesterol and LDL, followed by APOE3 and APOE2., This is largely attributed to APOE4 preferentially binding to VLDL and APOE3 to HDL. ${ }^{9}$

\section{The central nervous system}

In the central nervous system (CNS), APOE mainly produced by astrocytes (either pericytes or microglia) or under certain pathological conditions (eg, stressors, injurious agents) by neurons. ${ }^{3,10-12}$ This involves the redistribution of lipids among

Table I Plasma lipoproteins containing APOE

\begin{tabular}{lllll}
\hline Properties & Chylomicrons & VLDL & LDL & HDL \\
\hline Major & APOA-I & APOB & APOB & APOA-I \\
apolipoproteins & APOB & APOC-I & & APOA-II \\
& APOC & APOC-II & & \\
& & APOC-III & & \\
& & APOE & & \\
Minor & APOA-II & APOA-I & APOC & APOC-I \\
apolipoproteins & APOE & APOA-II & & APOC-II \\
& & APOD & & APOC-III \\
& & & & APOD \\
& & & & APOE \\
\hline
\end{tabular}

Abbreviations: APO, apolipoprotein; APOE, apolipoprotein E; HDL, high-density lipoprotein; LDL, low-density lipoprotein; VLDL, very-low-density lipoprotein. cells of different organs, including the CNS (Figure 1). ${ }^{10}$ The human brain contains up to $25 \%$ of the body's cholesterol, which is essential for myelin production, function, and integrity. Cholesterol homeostasis is important for normal brain functions, since it is an essential component for axonal growth, synaptic formation, and remodeling events that are crucial for learning and memory. ${ }^{13,14}$ Cholesterol in the CNS is regulated independently from that in the peripheral system. Cholesterol dysfunction in the CNS could be associated with aging and the development of certain neurodegenerative diseases. In the CNS, APOE mediates cholesterol neuronal delivery. ${ }^{15,16}$ The blood-brain barrier restricts the exchange of lipoproteins and APOE between the CNS and peripheral system. A study showed that injury to the brain resulted in an increase in APOE protein in the brain. ${ }^{17}$ More recently, two reports have suggested that brain APOE regulates the clearance of amyloid- $\beta(A \beta)$, which is a common hallmark of some neurological diseases. ${ }^{18,19}$ So far, the mechanisms involving APOE in all of these biological processes have not been completely clarified.

\section{$A P O E$ polymorphism and mutations}

The APOE gene is located on chromosome19q13.2. It contains four exons and three introns (Figure 2A), totaling 3,597 base pairs in a cluster with apolipoprotein $\mathrm{C} 1$ and apolipoprotein $\mathrm{C} 2$. Several individual SNPs have been identified in the human $A P O E$ gene. In particular, two SNPs, rs7412 $(\mathrm{C} / \mathrm{T})$ and $\mathrm{rs} 429358(\mathrm{C} / \mathrm{T})$, are responsible for the three major alleles: epsilon-2 (ع2), epsilon-3 (ع3), and epsilon-4 (ع4). Because human cells have two copies of each gene, there are six $A P O E$ genotypes: $\varepsilon 2 / \varepsilon 2, \varepsilon 2 / \varepsilon 3, \varepsilon 2 / \varepsilon 4, \varepsilon 3 / \varepsilon 3, \varepsilon 3 / \varepsilon 4$, and $\varepsilon 4 / \varepsilon 4$. They are responsible for three homozygous $(\varepsilon 2 / \varepsilon 2$, $\varepsilon 3 / \varepsilon 3$, and $\varepsilon 4 / \varepsilon 4)$ and three heterozygous ( $\varepsilon 2 / \varepsilon 3$, $\varepsilon 2 / \varepsilon 4$, and $\varepsilon 3 / \varepsilon 4)$ genotypes. ${ }^{11}$ The three major protein isoforms, APOE2, APOE3, and APOE4, differ from each other by only one or two amino acids at positions 112 and 158. These differences alter APOE structure and function, respectively (Figure 2C). 5,6

APOE4 is thought to be derived from E3 by a cysteineto-arginine (Cys $\rightarrow$ Arg) substitution at position 112 and is designated as E4 (Cys112 $\rightarrow$ Arg). ${ }^{5,6}$ So far, three forms of APOE2 have been described: E2 (Arg158 $\rightarrow$ Cys), E2 (Arg145 $\rightarrow$ Cys), and E2 (Lys146 $\rightarrow$ Gln). ${ }^{4}$ In isoelectric focusing, four different mutations give a band at the E2 position, E2 (Arg158 $\rightarrow$ Cys), E2 (Lys146 $\rightarrow$ Gln), E2 (Arg145 Cys), and E2-Christchurch (Arg136 $\rightarrow$ Ser). APOE2 (Arg158 $\rightarrow$ Cys) is the most common of the $\varepsilon 4{ }^{5,6}$ APOE1 has been reported to contain a Cys instead 


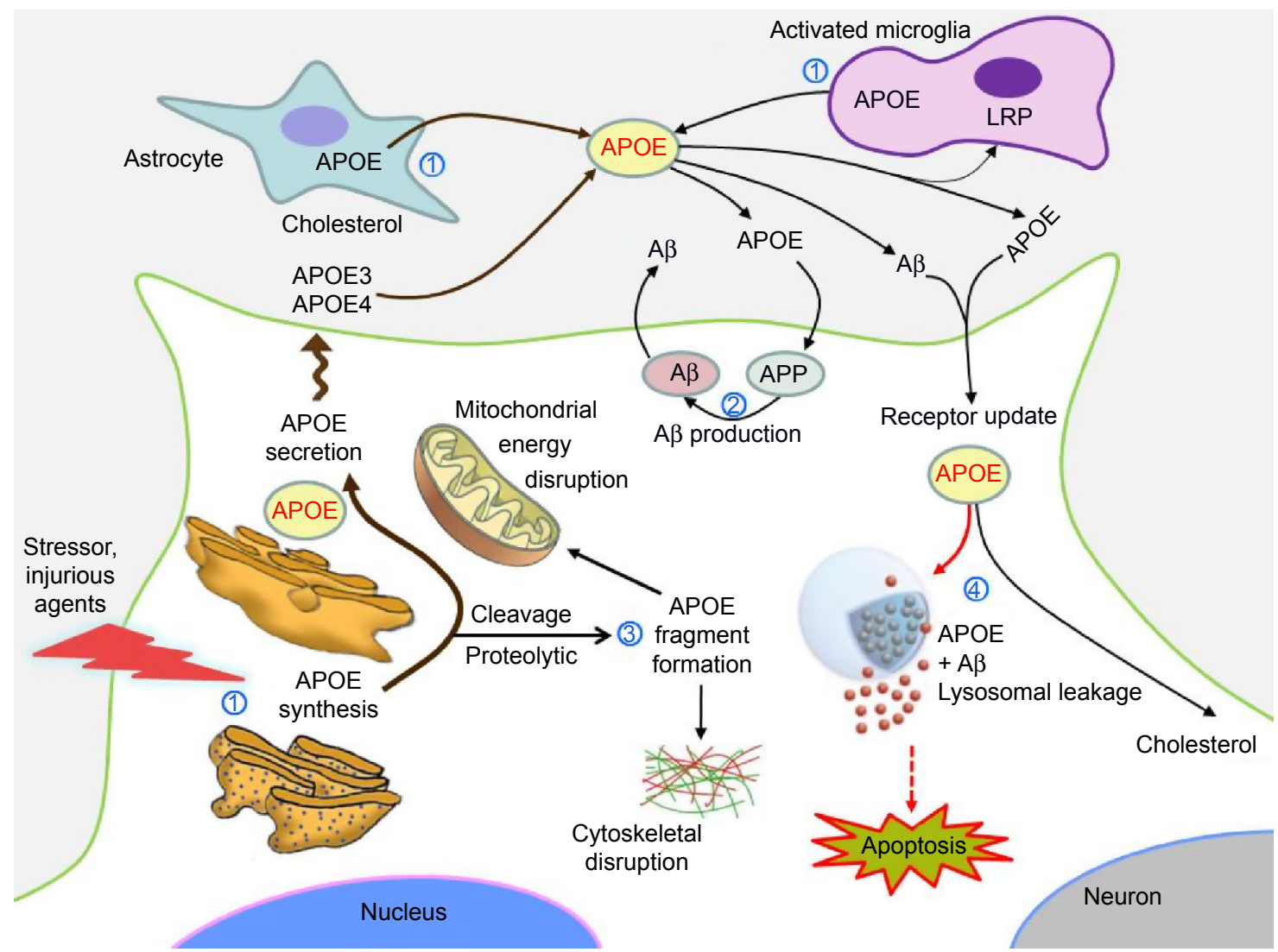

Figure I APOE formation and its role in redistribution of lipids to the cells of CNS: the neuropathological effects of the neurotoxic APOE fragments.

Notes: (1) APOE mainly produced by astrocytes, either pericytes, microglia, or under certain pathological conditions (stressors, injurious agents, etc). (2) The role of APOE in the production of $A \beta$ in association with APP. (3) The result of APOE fragmentation is associated with cytoskeletal disruption and mitochondrial dysfunction. (4) APOE isoform-specifically and $A \beta$-induced lysosomal leakage and apoptosis.

Abbreviations: A $\beta$, amyloid- $\beta$; APOE, apolipoprotein E; APP, amyloid precursor protein; LRP, lipoprotein receptor-related protein I; CNS, central nervous system.

of an Arg at position 158, similar to APOE2, as well as an additional amino acid substitution, which probably does not have any functional significance. ${ }^{20}$ In addition to these common polymorphisms, several mutations have been described (Table 2). APOE3 is the most-common isoform, while APOE4 and APOE2 are less-frequently observed. The $A P O E \varepsilon 3$ allele is present in $79 \%$ the entire population, whereas $A P O E$ \& 4 is only present in $13.3 \%$ and $A P O E$ \&2 in $7.3 \%$ of the population. ${ }^{21}$ Additionally, there are two rare alleles of the gene, $\varepsilon 1$ and $\varepsilon 5$, but these are present in $<0.1 \%$ of the population. ${ }^{20}$ The frequencies of the mostcommon alleles of $A P O E$ in various populations around the world show that geography, climate, isolation by local adaptations, genetic drift, and possibly evolutionary history selection are responsible for shaping the spectrum of $A P O E$ genetic variation (Table 2).

\section{APOE}

APOE is a 299 amino acid glycoprotein of $34.1 \mathrm{kDa}{ }^{1}$ The structure of this protein varies, depending on the genetic polymorphism. The protein contains two major structural domains, including a compact and stable globular amino-terminal domain (amino acid residues 20-166) and a less-stable carboxy-terminal domain (amino acid residues 225-299). ${ }^{22}$ These domains are connected to each other by a hinge region (amino acid residues 166-224). ${ }^{22}$ The LDL receptor-binding region is between residues $136-150$ of the protein, where multiple basic amino acids are present. ${ }^{23}$ The carboxy-terminal domain contains the major lipid-binding region..$^{24}$ The amino acid residues 245-266 appear to be critical for binding to VLDL particles, whereas binding to HDL occurs even without the carboxyl-terminal domain. ${ }^{25}$ The three major APOE isoforms differ from each other by two cysteine/arginine interchanges at position 112 and 158. APOE2, APOE3, and APOE4 contain cysteine/cysteine, cysteine/arginine, and arginine/arginine at these two positions, respectively (Figure $2 \mathrm{C}$ ). ${ }^{26}$

The APOE $\varepsilon 2$ allele carries the Arg158Cys polymorphism. It could disrupt the natural salt bridge between Asp154 
A

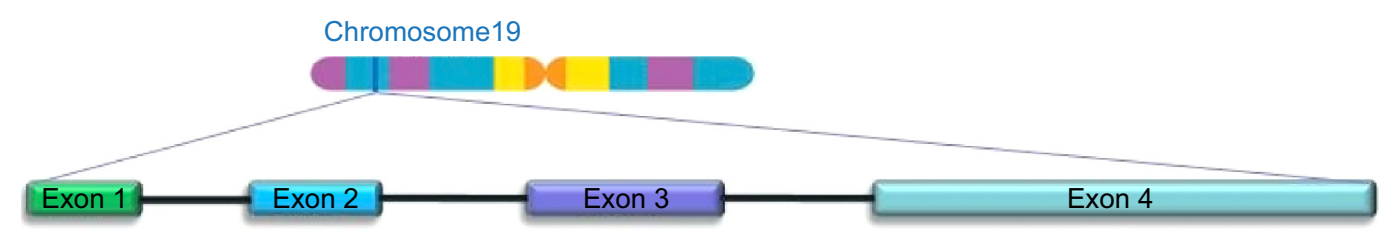

B

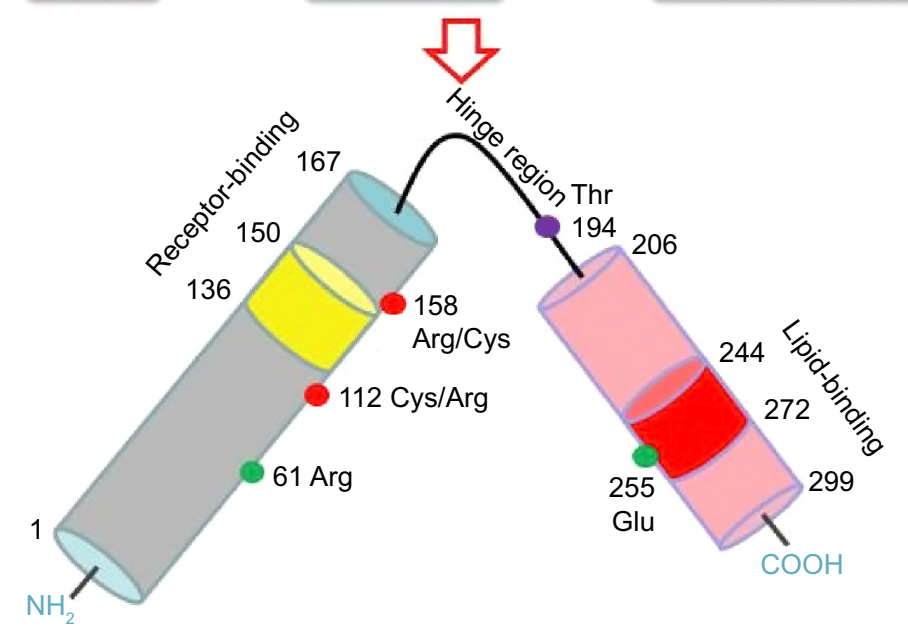

C

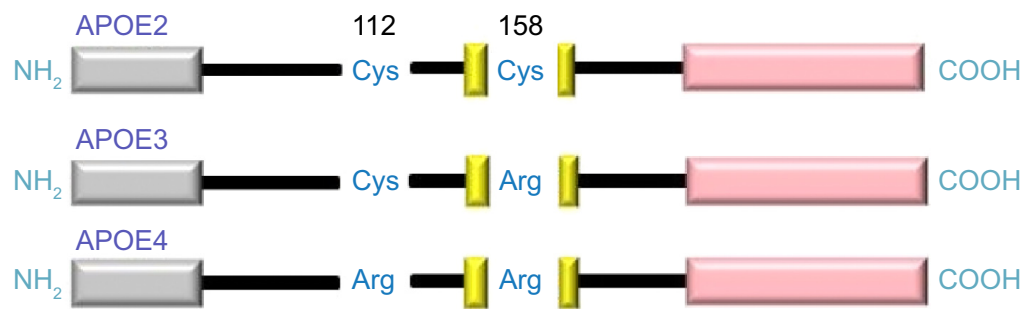

Signaling domain $\square$ Receptor-binding domain

Lipid-binding domain

Figure 2 Schematic Illustration of structural and functional regions of APOE.

Notes: (A) Location and structure of the APOE gene on chromosome 19. (B) APOE protein is a polypeptide chain with 299 amino acids consisting of a receptor-binding region (residues 136-150) in the N-terminal domain (residues I-167) and a lipid-binding region (residues 244-272) in the C-terminal domain (residues 206-299). (C) Three major APOE isoforms are located at residues II 2 and 158 (red circles), where APOE2 has Cys residues at both positions, APOE3 has a Cys residue at I I 2 and an Arg residue at I58, and APOE4 has Arg residues at both positions.

Abbreviation: APOE, apolipoprotein E.

and Arg158. In turn, a salt bridge was formed as the result of the interaction between Arg150 and Asp154. This bridge could disrupt receptor binding because Arg150 is part of the LDL binding site. ${ }^{27}$ This mutation was related to type III hyperlipoproteinemia (HLP). ${ }^{6}$ Exchange of Asp154 to an alanine could induce the disruption of the Arg150 and Asp154 bridge, and the receptor-binding activity could return to the normal level. Arg 150 could relocate within the receptor-binding region. ${ }^{2}$ APOE $\varepsilon 3$ allele presents a cysteine in position 112 and arginine in position $158 .{ }^{1}$

Arg112 mediates two key features of the $\varepsilon 4$ allele, as it is associated with reduced stability. The $\varepsilon 4$ allele could promote the domain interaction by the orientation of Arg61 on the N-terminal domain. Interaction with Glu255 in the $\mathrm{C}$-terminal domain could be an important structural propriety of the $\varepsilon 4$ allele, and $\varepsilon 2$ alleles might have less risk for domain interaction. Mutation of Arg61 to Thr (or Glu255 to Ala), was suggested to reduce the domain interaction, causing an ع3-like molecule (Figure 2B). ${ }^{3}$ In addition, mutation update and genotype-phenotype correlations of novel and previously described mutations in APOE are available in Table 3.

\section{Measurement of APOE}

APOE plays a role in the transport and metabolism of triglyceride-cholesterol. Genotyping could be used to improve the diagnosis of triglyceride cholesterol variants, and APOE polymorphisms were also associated with altered odds of having $\mathrm{AD}$ and other diseases. Determination of APOE level is of potential interest when studying different forms of brain damage and as a marker of ongoing regenerative processes in the brain. APOE is a polymorphic apolipoprotein exhibiting three major isoforms, $\varepsilon 2, \varepsilon 3$, and $\varepsilon 4$, at a single gene locus. 
Table 2 Relative frequencies of the most-common alleles for the gene locus coding for APOE in various populations of the world

\begin{tabular}{|c|c|c|c|c|c|}
\hline Population & $\mathbf{n}$ & $\varepsilon 2$ & $\varepsilon 3$ & $\varepsilon 4$ & Reference \\
\hline \multicolumn{6}{|l|}{ European } \\
\hline Lapp & 70 & 0.050 & 0.640 & 0.310 & 35 \\
\hline Swedish & 279 & 0.119 & 0.675 & 0.206 & 133 \\
\hline Danish & 466 & 0.085 & $0.74 I$ & 0.174 & 134 \\
\hline Finnish & 2,245 & 0.044 & 0.748 & 0.208 & 133 \\
\hline Dutch & 2,218 & 0.085 & 0.752 & 0.163 & 133 \\
\hline Belgian & 760 & 0.072 & 0.765 & 0.163 & 135 \\
\hline Icelandic & 185 & 0.068 & 0.767 & 0.165 & 133 \\
\hline United Kingdom & 734 & 0.089 & 0.767 & 0.144 & 133,136 \\
\hline French & 1,228 & 0.108 & $0.77 I$ & 0.121 & 133 \\
\hline German & 2,031 & 0.077 & 0.778 & 0.145 & 133 \\
\hline Norwegian & 395 & 0.087 & 0.781 & 0.132 & 133 \\
\hline Tyrolean & 469 & 0.090 & 0.789 & 0.117 & 133 \\
\hline Hungarian & 202 & 0.064 & 0.807 & 0.129 & 133 \\
\hline Swiss & 173 & 0.072 & 0.821 & 0.107 & 133 \\
\hline Polish & 137 & 0.055 & 0.839 & 0.106 & 137 \\
\hline Italian & 2,000 & 0.060 & 0.849 & 0.091 & 133 \\
\hline Spanish & 1,286 & 0.052 & 0.856 & 0.091 & $36,134,136,138$ \\
\hline Sardinian & 280 & 0.050 & 0.898 & 0.052 & 133 \\
\hline \multicolumn{6}{|l|}{ African } \\
\hline Zambian & 116 & 0.138 & 0.598 & 0.267 & 139 \\
\hline Brazilian & 123 & 0.610 & 0.805 & 0.134 & 140 \\
\hline Pygmy & 70 & 0.057 & 0.536 & 0.047 & $14 \mid$ \\
\hline Khoisan & 247 & 0.077 & 0.553 & 0.370 & 142 \\
\hline Moroccan & 100 & 0.065 & 0.850 & 0.085 & 138 \\
\hline Nigerian & 365 & 0.027 & 0.677 & 0.296 & 143 \\
\hline Sub-Saharan & 470 & 0.116 & 0.706 & 0.178 & $|4|$ \\
\hline Beninese & 97 & 0.103 & 0.742 & 0.155 & 144 \\
\hline Ethiopian & 164 & 0.031 & 0.811 & 0.143 & 144 \\
\hline Sudanese & 105 & $0.08 \mathrm{I}$ & 0.619 & 0.291 & 143 \\
\hline \multicolumn{6}{|l|}{ Asian } \\
\hline Bangladeshi & 53 & 0.050 & 0.800 & 0.150 & 145 \\
\hline Indian & 497 & $0.05 I$ & $0.88 I$ & 0.068 & 21 \\
\hline Malay Aboriginal & 223 & 0.140 & 0.620 & 0.240 & 146 \\
\hline Malay & 118 & 0.114 & 0.767 & 0.119 & 143 \\
\hline Chinese & $\mathrm{I}, 034$ & 0.105 & 0.824 & $0.07 I$ & $76,134,143,147$ \\
\hline Japanese & $\mathrm{I}, 097$ & 0.048 & 0.851 & 0.101 & 143 \\
\hline Korean & 305 & 0.127 & 0.750 & 0.121 & 148 \\
\hline \multicolumn{6}{|l|}{ Native American } \\
\hline Cayapa & 91 & 0.000 & 0.720 & 0.280 & 149 \\
\hline Amerindian & 110 & 0.000 & 0.816 & 0.184 & 150 \\
\hline Yanomami & 96 & 0.000 & 0.844 & 0.156 & $15 \mid$ \\
\hline Mayan & 135 & 0.000 & 0.911 & 0.089 & 150 \\
\hline \multicolumn{6}{|l|}{ Oceanian } \\
\hline Papuan & 110 & 0.145 & 0.486 & 0.368 & 150 \\
\hline Polynesian & 111 & 0.110 & 0.630 & 0.260 & 150 \\
\hline $\begin{array}{l}\text { Aboriginal } \\
\text { Australian }\end{array}$ & 64 & 0.0 & 0.740 & 0.260 & 150 \\
\hline
\end{tabular}

Abbreviation: APOE, apolipoprotein E.

APOE isoform-specific effects on APOE/A $\beta$ complex levels may mediate the increase in soluble $A \beta$ levels that correlate with APOE4. Allelic variations in $A P O E$ were consistently associated with plasma concentrations of total cholesterol, LDL cholesterol, and APOB (the major protein of LDL,
VLDL, and chylomicrons). $A P O E \varepsilon 2$ was studied in disorders associated with elevated cholesterol levels or lipid derangements such as type III HLP, coronary heart disease, stroke, peripheral artery disease, and diabetes mellitus. ${ }^{8} A P O E \varepsilon 2$ was established as an important marker for diagnosis. $A P O E \varepsilon 4$ is a major genetic risk factor for neurodegenerative diseases such as $\mathrm{AD}$ and PD. ${ }^{28-30}$

Methods have been developed to detect individual $A P O E$ phenotype or genotype. Studies indicated that the method for detection and the source of the components for APOE/A $\beta$ complex were critical parameters for the experimental outcome. So far, many methods have been developed to measure APOE/A $\beta$ complex, including gel-shift assay on sodium dodecyl sulfate-polyacrylamide gel electrophoresis, Western blot analysis, ${ }^{31}$ co-immunoprecipitation, ${ }^{31}$ size-exclusion chromatography/gel-filtration, and enzyme-linked immunosorbent assay. ${ }^{32}$ Some $A P O E$ variants that were defective in their ability to mediate the binding of lipoproteins to the LDL receptor and that are associated with diseases were poorly recognized by antibodies. Moreover, numerous studies have been developed to measure the effect of $A P O E$ polymorphism on APOE/A $\beta$ complex formation using these methods (Table 4).

\section{APOE-associated diseases}

Understanding structural differences in APOE isoforms helped establish the molecular mechanism responsible for the associated pathology. Defects in APOE could result in alterations in its structure and function..$^{33}$ The critical effect of APOE in regulating plasma lipid and lipoprotein levels has been extensively and carefully studied. ${ }^{3,13,33-37}$ Evidence indicates its association with neurodegenerative diseases and also other chronic diseases. This review will summarize the critical available data related to APOE defects and their role in $\mathrm{AD}, \mathrm{PD}, \mathrm{CVD}$, type III HLP, MS, T2DM, VD, and IS (Figure 3).

\section{Alzheimer's disease}

AD was originally described by Alois Alzheimer in 1907. ${ }^{38}$ It is the most-common age-related dementing illness, which is currently estimated to affect 35.6 million individuals worldwide. ${ }^{39}$ It was estimated that the number of patients with AD will triple by $2050 .{ }^{40} \mathrm{APOE}$ plays a critical role in transporting cholesterol in and out of the CNS and is also recognized as the most important risk factor for the lateonset form of AD. The distribution of APOE's three major alleles, $\varepsilon 2, \varepsilon 3$, and $\varepsilon 4$, in patients with $\mathrm{AD}$ is $3.9 \%, 59.4 \%$, and $36.7 \%$, respectively. ${ }^{30}$ Based on the strong association between APOE and A $\beta$ in the brain, ${ }^{41}$ APOE was suggested 
Table 3 Variants of human APOE

\begin{tabular}{|c|c|c|c|}
\hline Type of genetic variation & Designation & Disease association & Reference \\
\hline \multirow[t]{40}{*}{ Point mutation } & El (Gly I27 $\rightarrow$ Asp, ArgI58 $\rightarrow$ Cys) & HLP & 85 \\
\hline & EI (LysI46 $\rightarrow$ Glu) & Type III HLP & 81 \\
\hline & El (LysI46 $\rightarrow$ Asn; ArgI47 $\rightarrow$ Trp) & Type III HLP & 79 \\
\hline & El (ArgI58 $\rightarrow$ Cys; ArgI80 $\rightarrow$ Cys) & Hypertriglyceridemia & 80 \\
\hline & El (Arg158 $\rightarrow$ Cys; Leu252 $\rightarrow$ Glu) & Type Ila HLP & 152 \\
\hline & E2 $(\operatorname{Arg} 25 \rightarrow$ Cys $)$ & Type III HLP & 153 \\
\hline & E2 (Argl $34 \rightarrow$ Glu) & & 78 \\
\hline & E2 (ArgI36 $\rightarrow$ Ser) & Type III or V HLP & 154 \\
\hline & E2 (Argl36 $\rightarrow$ Cys) & Type III HLP & 82,84 \\
\hline & E2 (Argl42 $\rightarrow$ Leu) & Type III HLP & 155 \\
\hline & E2 (Argl45 $\rightarrow$ Cys) & Type III HLP & 4 \\
\hline & E2 (Argl $45 \rightarrow$ Prol) & Lipoprotein glomerulopathy & 156 \\
\hline & E2 (Lys I 46 $\rightarrow$ Gln) & Type III HLP & 78,83 \\
\hline & $\mathrm{E} 2(\mathrm{G} \ln \mathrm{I} 87 \rightarrow \mathrm{Glu})$ & Type III HLP & 157 \\
\hline & E2 (Arg224 $\rightarrow$ Gln) & Xanthomatosis & 158 \\
\hline & & Hyperlipidemia & \\
\hline & E2 (Arg228 $\rightarrow$ Cys) & Type IV or V HLP & 159 \\
\hline & E2 (Val236 $\rightarrow$ Glu) & Type Ilb or IV HLP & 152 \\
\hline & E3 $($ Ala99 $\rightarrow$ Thr; Alal $52 \rightarrow$ Prol $)$ & Hyperlipidemia & 160,161 \\
\hline & E3 $($ Ala I06 $\rightarrow$ Val $)$ & Hypertriglyceridemia & 162 \\
\hline & & Alzheimer's disease & \\
\hline & E3 (CysII2 $\rightarrow$ Arg; ArgI42 $\rightarrow$ Cys) & Type III HLP & I \\
\hline & E3 (CysI I $\rightarrow$ Arg; Arg25I $\rightarrow$ Gly) & Type IV HLP & 152 \\
\hline & E3 (Argl36 $\rightarrow$ His) & Type III HLP & 163 \\
\hline & E3 $($ Thr42 $\rightarrow$ Ala $)$ & & 164 \\
\hline & E3 (Argl $45 \rightarrow$ His) & Hyperlipidemia & 165 \\
\hline & E4 (Glul3 $\rightarrow$ Lys; ArgI $45 \rightarrow$ Cys) & Type III HLP & 135,166 \\
\hline & E4 (Leu28 $\rightarrow$ Prol; CysI I2 $\rightarrow$ Arg)m & Alzheimer's disease & 167,168 \\
\hline & & Coronary artery disease & \\
\hline & & Types Ila, Ilb, IV, and V HLP & \\
\hline & E4 (Cys I I $\rightarrow$ Arg; Arg274 $\rightarrow$ His) & & 152 \\
\hline & E4 (Ser296 $\rightarrow$ Arg) & & 152 \\
\hline & E5 (Glu3 $\rightarrow$ Lys) & Hypercholesterolemia & 169 \\
\hline & E5 (Glu $3 \rightarrow$ Lys) & & 170 \\
\hline & E5 (Gln8I $\rightarrow$ Lys; CysII2 $\rightarrow$ Arg) & Hypercholesterolemia & $|7|$ \\
\hline & E5 (Pro84 $\rightarrow$ Arg; CysI I2 $\rightarrow$ Arg) & & 169 \\
\hline & E5 (Glu2I2 $\rightarrow$ Lys) & & 172 \\
\hline & E7 (Glu244 $\rightarrow$ Lys; Glu245 $\rightarrow$ Lys) & Hyperlipidemia & 173,174 \\
\hline & $\mathrm{E}_{\text {Null }}(\operatorname{Trp} 210 \rightarrow$ Stop $)$ & Type III HLP & 175 \\
\hline & $\mathrm{E}_{\text {Null }}($ TGG20 $\rightarrow$ Stop $)$ & HLP & 176 \\
\hline \multirow[t]{6}{*}{ Deletion } & $\mathrm{EI}(\mathrm{G} \ln |56-\mathrm{Gly}| 73 \rightarrow 0)$ & Lipoprotein glomerulopathy & 177 \\
\hline & & Systemic atherosclerosis & \\
\hline & EI (Leul4I-Lys|43 $\rightarrow 0$ ) & Lipoprotein glomerulopathy & 178 \\
\hline & $\mathrm{E}_{\text {Null }}($ Leu60 $\rightarrow$ Stop $)$ & Hyperlipidemia & 179 \\
\hline & $\mathrm{E}_{\text {Null }}($ Leu229 $\rightarrow$ Stop $)$ & Type III HLP & 180 \\
\hline & APOE protein is abnormally spliced & Type III HLP & $|8|$ \\
\hline \multirow[t]{2}{*}{ Insertion } & E3 (Cys I I2 $\rightarrow$ Arg, duplication I20-126) & Type IV HLP & 182 \\
\hline & E5 (duplication I35-I42) & Type IV HLP & 183 \\
\hline
\end{tabular}

Abbreviations: APOE, apolipoprotein E; HLP, Hyperlipoproteinemia.

as an $\mathrm{A} \beta$-binding protein that induces a pathological $\beta$ sheet conformational change in $\mathrm{A} \beta .^{42}$ APOE $\varepsilon 4$ suggests probably increases the risk of $A D$ by initiating and accelerating $A \beta$ accumulation, aggregation, and deposition in the brain. Cleavage of APOE4 may increase AD risk in two ways, either through a loss of function or gain of toxicity. ${ }^{30}$ Genome-wide association studies have shown that the $A P O E$ \&4 allele is associated with $\mathrm{AD},{ }^{43-45}$ and was detected in homogeneous and heterogeneous populations in North America, Europe, and Asia. ${ }^{46-48}$ 
Table 4 The methods utilized to measure APOE/A $\beta$ levels

\begin{tabular}{|c|c|c|c|}
\hline Human APOE source & Detection method & Results & Reference \\
\hline \multirow[t]{2}{*}{ Human plasma (purified) } & SDS-PAGE (nonreducing), WB & APOE $4 / A \beta>A P O E 3 / A \beta$ & 45 \\
\hline & & Stability at $4.6 \mathrm{pH}=\mathrm{APOE} 3 / \mathrm{A} \beta>\mathrm{APOE} / \mathrm{A} \beta$ & \\
\hline Human plasma (purified) & SDS-PAGE (nonreducing), WB & APOE $3 / A \beta>A P O E 4 / A \beta$ & 184 \\
\hline Human brain (AD and NAD) & SDS-PAGE & $A D>N A D$, no APOE isoform differences measured & 41 \\
\hline Human plasma (purified) & Surface plasmon resonance & $\mathrm{APOE} 3 / \mathrm{A} \beta>\mathrm{APOE} 4 / \mathrm{A} \beta=\mathrm{APOE} 2 / \mathrm{A} \beta$ & 185 \\
\hline $\mathrm{CHO}(\mathrm{CM})$ & SDS-PAGE (nonreducing), WB & $\mathrm{APOE} 3 / \mathrm{A} \beta=\mathrm{APOE} 2 / \mathrm{A} \beta>>\mathrm{APOE} 4 / \mathrm{A} \beta$ (ND) & 186 \\
\hline \multicolumn{4}{|l|}{ Human plasma } \\
\hline \multirow[t]{4}{*}{ Human plasma APOE } & IP with SDS-PAGE, WB & NAD APOE $23 / A \beta=N A D$ & 31 \\
\hline & & $\mathrm{APOE} 33 / \mathrm{A} \beta=\mathrm{NAD} A \mathrm{APOE} 34 / \mathrm{A} \beta>\mathrm{AD} A \mathrm{APOE} 33 / \mathrm{A} \beta$ & \\
\hline & & $>$ AD APOE44/A $\beta$ & \\
\hline & & SDS and protease digestion stability: NAD $>A D$ & \\
\hline $\begin{array}{l}\text { Recombinant (nonlipidated } \\
\text { and lipidated) }\end{array}$ & ELISA & $\mathrm{APOE} 2 / \mathrm{A} \beta>\mathrm{APOE} 3 / \mathrm{A} \beta>\mathrm{APOE} 4 / \mathrm{A} \beta$ & 174 \\
\hline $\begin{array}{l}\text { RAW264 and HEK293 (CM, } \\
\text { delipidated) }\end{array}$ & ELISA & $\begin{array}{l}\text { CM and Sf9 (lipidated): } A P O E 3 / A \beta>A P O E 4 / A \beta \\
\text { All sources (delipidated): } A P O E 3 / A \beta=A P O E 4 / A \beta\end{array}$ & 32 \\
\hline \multicolumn{4}{|l|}{$\begin{array}{l}\text { Sf9 insect cells (delipidated } \\
\text { and lipidated) }\end{array}$} \\
\hline RAW264 (CM) & Co-IP, SDS-PAGE & CM: APOE $3 / A \beta>>A P O E 4 / A \beta$ & 187 \\
\hline $\begin{array}{l}\text { CSF (NAD } \varepsilon 3 / \varepsilon 3, \text { PAD } \varepsilon 3 / \varepsilon 4 \\
\text { AD } \varepsilon 4 / \varepsilon 4)\end{array}$ & (nonreducing), WB & CSF: APOE33/A $\beta>$ APOE34/A $\beta=$ APOE4/A $\beta$ (ND) & \\
\hline (Lipidated) & SDS-PAGE (nonreducing), WB & APOE3/sA $\beta>$ APOE3/agg A $\beta$ & 188 \\
\hline \multicolumn{4}{|l|}{ Recombinant } \\
\hline HEK293 (CM) & $\begin{array}{l}\text { (Nonreducing), WB } \\
\text { SDS-PAGE }\end{array}$ & $\begin{array}{l}\text { APOE } 3 / \circ A \beta>A P O E 3 / A \beta \text { fibrils }>\text { APOE } 4 / O A \beta> \\
\text { APOE } 4 / A \beta \text { fibrils }\end{array}$ & 33 \\
\hline $\begin{array}{l}\text { (Lipidated) } \\
\text { Recombinant }\end{array}$ & ELISA & $\begin{array}{l}\text { Intermediate agg } A \beta 40: A P O E 4 / A \beta>>A P O E 2 / A \beta= \\
\text { APOE3/A } \beta\end{array}$ & 189 \\
\hline $\begin{array}{l}\text { Escherichia coli (purified and } \\
\text { lipidated) }\end{array}$ & EPR spectroscopy & $\begin{array}{l}\text { Purified APOE: APOE } 3 / \circ A \beta>\text { APOE } 4 / O A \beta \\
\text { Lipidated APOE: APOE3/A } \beta>\text { APOE } 4 / A \beta\end{array}$ & 190 \\
\hline Human plasma (NAD) & SEC, SDS-PAGE & $95 \% A \beta$ elutes with lipoproteins & 34 \\
\hline Human CSF (NAD) & (nonreducing), WB & $\begin{array}{l}\text { I00\% A } \beta \text { associated with APOE-containing lipoproteins } \\
\text { APOE monomer/A } \beta(45 \mathrm{kDa}) \text { and APOE dimer/A } \beta \\
(97 \mathrm{kDa}) \text { detected }\end{array}$ & \\
\hline Hippocampal homogenates & ELISA & SDS stable: E2FAD > E3FAD > E4FAD & 191 \\
\hline (EFAD mice) & & Total complex: E2FAD = E3FAD $>$ E4FAD & \\
\hline Human cortical synaptosomes & & Total complex: & \\
\hline$(A D$ and $N A D)$ & & $N A D>A D$ & \\
\hline Human CSF (AD and NAD) & & NAD APOE $33 / A \beta=$ NAD APOE $4 X / A \beta>>A D$ & \\
\hline & & APOE $33 / A \beta>A D$ APOE $4 X / A \beta$ & \\
\hline & & SDS stable: & \\
\hline & & NAD APOE $33 / A \beta>>$ NAD APOE $4 / A \beta$ & \\
\hline & & $\begin{array}{l}N A D>A D, N A D \text { APOE33/A } \beta>A D \text { APOE33/A } \beta> \\
A D \text { APOE44/A } \beta\end{array}$ & \\
\hline
\end{tabular}

Abbreviations: $A \beta$, amyloid- $\beta$; $A D$, Alzheimer's disease; agg $A \beta$, aggregated amyloid- $\beta$; $A P O E$, apolipoprotein $E$; $C H O$, Chinese hamster ovary cell; $C M$, conditioned media; co-IP, co-immunoprecipitation; CSF, cerebrospinal fluid; EFAD, essential fatty acid deficiency; EPR, electron paramagnetic resonance; ELISA, enzyme-linked immunosorbent assay; IP, immunoprecipitation; NAD, non-Alzheimer's disease or nondementia control; ND, not detectable; oA $\beta$, oligomeric amyloid- $\beta$; PAD, probable Alzheimer's disease; PAGE, polyacrylamide gel electrophoresis; sA $\beta$, soluble amyloid- $\beta$; Sf9, Spodoptera frugiperda insect cells; SDS, sodium dodecyl sulfate; SEC, size-exclusion chromatography; WB, Western blot.

Since the relationship between APOE immunoreactivity and amyloid plaques was first reported, ${ }^{42,49}$ the $\varepsilon 4$ allele has shown to be strongly associated with both late-onset familial ${ }^{45,50}$ and sporadic $\mathrm{AD}{ }^{43,44}$ It is estimated to be the principal genetic factor in up to $50 \%$ of all cases of $\mathrm{AD}^{51,52}$ Moreover, risk for $\mathrm{AD}$ was increased two- to threefold in individuals who carried the heterozygous $\varepsilon 4$ allele and about 12 -fold in those who carried the homozygous $\varepsilon 4$ allele..$^{51,53}$ Conversely, there was evidence suggesting that the $A P O E$ \&2 allele may be protective against $\mathrm{AD}$ or associated with a marked reduction in $\mathrm{AD}$ risk. ${ }^{54,55} \mathrm{AD}$ risk in the $A P O E \varepsilon 2 / \varepsilon 2$ or $\varepsilon 2 / \varepsilon 3$ carriers was lower than in those carrying $\varepsilon 3 / \varepsilon 3 .{ }^{55} \mathrm{APOE}$ 's role in $\mathrm{AD}$ is well established. Therefore, further studies are needed to understand the possible association between APOE and the rate of disease progression. APOE was classified as a risk factor for $\mathrm{AD}$, but the molecular events that precede dementia remain elusive. APOE4 was suggested to be associated with damage of the vascular system in the brain, leading to $\mathrm{AD}$ pathogenesis. 


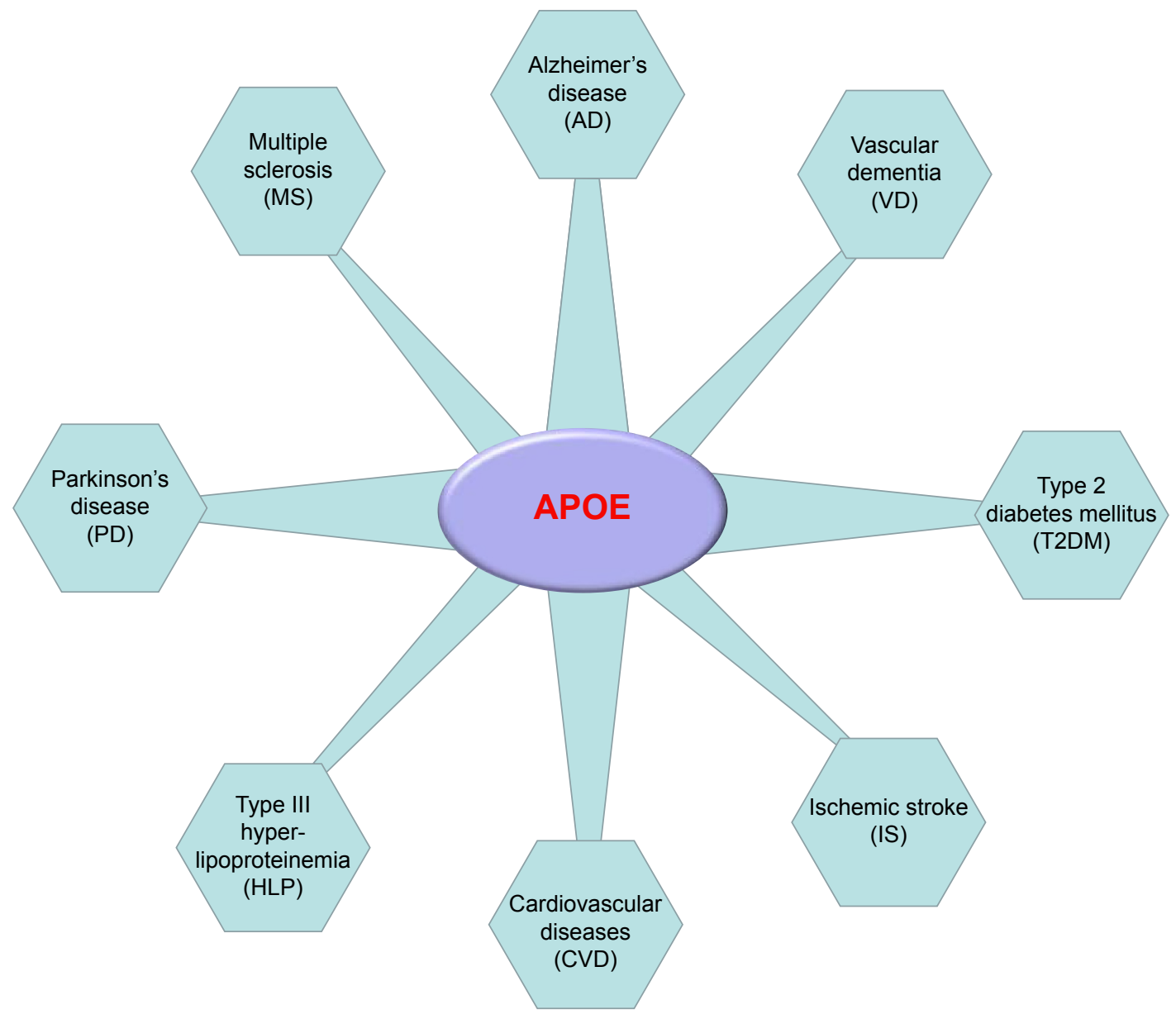

Figure 3 APOE is associated with disease progression in various conditions. Abbreviation: APOE, apolipoprotein E.

\section{Vascular dementia}

VD is a general term describing problems with reasoning, planning, judgment, memory and other thought processes caused by brain damage from impaired blood flow to your brain. The problem with this disease is the lack of consensus on the pathological criteria required for the exact diagnosis. The prevalence of VD in individuals older than 65 years of age is estimated to be $1.2 \%-4.2 \%$. Moreover, there are an estimated $6-12$ cases per 1,000 persons older than 70 years of age per year. ${ }^{56}$ It is difficult to distinguish the prevalence between VD and other pathologies, as $20 \%-30 \%$ of demented subjects show mixed pathologies. ${ }^{57}$ Clinically, VD and AD share pathological features such as the presence of neurofibrillary tangles, amyloid plaques, whitematter lesions, and cerebral amyloid angiopathy. ${ }^{58}$

There are many VD risk factors, including hypertension, stroke, atherosclerosis, and other metabolic disorders. However, APOE was also considered as an important risk factor for VD. The role of APOE4 in the development of VD might be an area of intensive investigation, with conflicting conclusions. The consumption of highly saturated fat and cholesterol may confer added risk for the development of $\mathrm{VD}$, which would be aggravated even more in people carrying the $\varepsilon 4$ allele. ${ }^{59,60}$ Some studies have shown a positive association between harboring the $\varepsilon 4$ allele and increased risk for VD, ${ }^{61-64}$ while others have indicated that $\varepsilon 4$ allele might not be associated with VD risks. ${ }^{65,66}$ Recent meta-analyses have revealed evidence of an increased VD risk in individuals with $A P O E$ \& 4 compared with $A P O E \varepsilon 33 .{ }^{64}$ Besides, $A P O E \varepsilon 4$ contribution to the risk of vascular cognitive impairment is independent of other vascular risk factors, including hypertension, dyslipidemia, and atherogenesis ${ }^{67}$ The presence of APOE in patients with VD could provide pathological evidence supporting the potential link between $A P O E$ polymorphism and enhanced risk for VD.

\section{Cardiovascular diseases}

CVD, including coronary heart disease, refers to any diseases that affect the cardiovascular system - principally cardiac 
disease, vascular diseases of the brain and kidney, and peripheral artery disease. ${ }^{68}$ The biological activity of APOE can be influenced by modification of its structure and/or quantity. Epidemiologic studies have indicated the direct association between APOE and CVD as well as its impact on cholesterol levels. In a study in middle-aged men, it was estimated that $40 \%$ of the $\varepsilon 4$ carrier population had an increased risk for CVD mortality compared with individuals with the $\varepsilon 3 / \varepsilon 3$ or $\varepsilon 2$ genotypes. ${ }^{69}$ Studies indicated that $\varepsilon 4$ carriers had an increased risk of death from CVD. ${ }^{35,70,71}$ Certain studies have linked the $\varepsilon 4$ allele with a greater risk for coronary artery disease and myocardial infarction. Indicatively, higher frequency of $\varepsilon 4$ was associated with higher cholesterol levels and higher CVD mortality rates in Finland, Scotland, and Northern Ireland. ${ }^{71,72}$ Furthermore, an increased CVD risk was also associated with the $\varepsilon 2$ allele. ${ }^{70} \mathrm{~A}$ report on the frequency of $A P O E$ genotype and its related CVD indicated that American Indians, Asians, and Mexican Americans presented the highest frequency of E3 (>84\%). Africans and African Americans presented the highest frequency of E4 (20.1\% and 31\%, respectively). African Americans and Caucasians (except Finns) presented the highest frequency of E2 $(7.3 \%-13.1 \%){ }^{8}$

So far, several studies have suggested that the $A P O E \varepsilon 4$ allele is a risk allele for CVD, while others failed to find any association. The dual role of APOE remains enigmatic and needs to be further explored in order to elucidate its precise role in cardiovascular and cerebrovascular diseases.

\section{Type III hyperlipoproteinemia}

Type III HLP, also known as dysbetalipoproteinemia or broad beta disease, is a genetic disorder characterized by accumulation of remnant lipoproteins in the plasma and development of premature atherosclerosis. ${ }^{10}$ Type III HLP results from the accumulation of chylomicron remnants from intestinal lipoproteins and VLDL remnants derived from hepatic lipoproteins. The expression of different isoforms of APOE that do not bind to the receptor ${ }^{2,10,73}$ and APOE deficiency was associated with the development of type III HLP. ${ }^{74,75}$ The primary molecular cause of type III HLP was also associated with the presence of APOE2. ${ }^{6}$ APOE2 increased triglyceride and cholesterol levels, leading to delayed clearance of hepatic and intestinal remnant lipoproteins, resulting in type III HLP. ${ }^{3}$ The development of overt hyperlipidemia requires the inheritance of two alleles of $A P O E \varepsilon 2$, and most $\varepsilon 2 / \varepsilon 2$ allele carriers are either normolipidemic or even hypocholesterolemic. Some studies showed that type III HLP could occur with a frequency of $1-5$ per 5,000 individuals.
Meanwhile, in Caucasian populations, type III HLP occurred with a frequency of $0.5-1.0$ per 100 individuals with the appearance of $\varepsilon 2 / \varepsilon 2$ homozygosity. ${ }^{73,76}$ Moreover, more than $90 \%$ of patients with type III HLP were homozygous for the $\varepsilon 2 / \varepsilon 2$ (Arg158 $\rightarrow$ Cys) allele, and the disease is normally considered as a recessively inherited multifactorial trait. ${ }^{77} \mathrm{On}$ the other hand, a variety of rare naturally occurring APOE mutations were also described that are associated with the dominant mode of inheritance of type III HLP at an early age. $^{78-85}$

\section{Parkinson's disease}

PD and AD share some clinical and neuropathological features. ${ }^{86} \mathrm{PD}$ progresses slowly in most people, affecting $2 \%$ of the population older than 65 years of age. ${ }^{29}$ APOE isoforms might affect degenerative processes by changing the lipid metabolism. In the CNS, the association between APOE and PD has been demonstrated. ${ }^{87,88}$ Most studies failed to report any association between $A P O E \varepsilon 4$ and susceptibility to PD and PD-associated dementia. ${ }^{28,29}$ Thus, several studies focused on $\varepsilon 4$ as a risk factor for age of onset and decrease in cognitive impairment associated with dementia in PD. However, $\varepsilon 2$ was considered as a weak or inconsistent risk factor for PD. ${ }^{29,89-91}$ One meta-analysis indicated that the $\varepsilon 2$ allele was associated with higher risk of PD development, ${ }^{92,93}$ whereas another study indicated that the $\varepsilon 4$ allele could be responsible for PD development. ${ }^{87}$ So far, studies focusing on the role of APOE in PD remain largely inconclusive.

\section{Type 2 diabetes mellitus}

T2DM is typically a chronic disease, and its prevalence increases with age. T2DM is also the predominant type, accounting for $90 \%$ of diabetes mellitus cases. ${ }^{94}$ T2DM has been affecting nearly $4 \%$ of the world's population, and it may be increasing up to $5.4 \%$ by year $2025 .{ }^{95}$ The development of T2DM could be caused by a combination of lifestyle and genetic factors. ${ }^{96,97}$ Recently, studies have showed that older patients with T2DM have a higher risk of cognitive dysfunction or dementia. ${ }^{98}$ Moreover, T2DM was related not only to VD, but also to the clinical diagnosis of AD-type dementia. ${ }^{99}$

APOE could play an important role in the regulation of plasma and cellular lipid concentrations, ${ }^{37}$ and APOE isoforms could present differences in chemical stability. ${ }^{100}$ $A P O E$ polymorphism could be one of the factors that affects the development of T2DM. Some studies demonstrated that $A P O E \& 2$ allele was associated with an increased risk of T2DM. ${ }^{101-104}$ In addition, global statistics show that the large burden of T2DM is restricted to developed countries. 
It is also a remarkable problem for developing countries such as People's Republic of China ${ }^{105}$ and India. ${ }^{106}$ A meta-analysis of 29 studies, which included 4,615 T2DM cases and 2,867 controls in the Chinese Han population, indicated that the $A P O E \varepsilon 2$ and $\varepsilon 4$ alleles may be associated with increased risk of T2DM and diabetic nephropathy. ${ }^{107}$ In addition, some studies have indicated that $A P O E \varepsilon 4$ associated with the risk of T2DM. ${ }^{108-110}$ In fact, deficits in cognitive performance were observed only for those with T2DM and, at least, one APOE $\varepsilon 4$ allele. ${ }^{111}$ The association between T2DM and AD was particularly strong among carriers of the $A P O E \varepsilon 4$ allele. T2DM is associated with reduced cognitive function and the incidence of dementia, including AD. The underlying mechanism of this association should be elucidated.

\section{Multiple sclerosis}

MS is the most-common autoimmune disorder affecting the CNS. ${ }^{112}$ The disease usually begins between the ages of 20 and 50, and it could be twice as common in women as in men. ${ }^{113} \mathrm{~A}$ genetic linkage between the chromosome 19 q13 region and MS has been demonstrated. ${ }^{114,115}$ So far, its association with $A P O E$ genotype remains unclear, and study results have been inconsistent. Some studies suggested that $A P O E \& 4$ might be a modifier of MS progression, increasing damage to the brain and worsening cognitive dysfunction and disease severity. ${ }^{116,117}$ However, these conclusions remained controversial. ${ }^{118}$ The possible association between $\varepsilon 4$ and cognitive dysfunction in MS has been investigated in a handful of studies with conflicting results. ${ }^{117,119,120}$ However, APOE $\varepsilon 4$ allele has been indicated as a risk factor for cognitive impairment in MS. ${ }^{16,117,119,121}$ Furthermore, patients with MS who carried the $\varepsilon 4$ allele were also reported to present verbal memory deficits. ${ }^{19,122}$ Recently, a study indicated that both $\varepsilon 2$ and $\varepsilon 4$ exert relevant effects on MS susceptibility, on the basis of combined data from 13,913 MS cases and 15,831 controls. ${ }^{123}$ So far, APOE association studies in MS have mostly yielded negative results, with some studies reporting significant effects and others being unable to confirm these associations.

\section{Ischemic stroke}

IS is one of the most frequent causes of mortality and disability worldwide. ${ }^{124}$ Approximately 17 million people had a stroke in 2010, and 33 million people have previously had a stroke and were still alive according to the World Health Organization. Moreover, overall two-thirds of strokes occurred in individuals older than 65 years of age. ${ }^{125}$ IS shares several risk factors with heart disease and it also occurs when an artery to the brain is blocked. APOE may have an impact on stroke occurrence. The $\varepsilon 4$ allele was associated with increased levels of LDL and cholesterol as well as ischemic heart disease. ${ }^{8,126}$ Initial studies assessing outcomes after IS demonstrated that $A P O E \varepsilon 4$ was not associated with poor prognosis, ${ }^{127,128}$ and a meta-analysis reported a significant association between IS and the $\varepsilon 4$ allele. ${ }^{129}$ Recently, IS prevalence was demonstrated to be significantly greater in $\varepsilon 4$ carrier patients. ${ }^{130}$ Furthermore, a meta-analysis of 22 published studies with a total of 30,879 subjects showed that the $\varepsilon 4$ allele was related to increased carotid intima-media thickness, a factor associated with IS. ${ }^{131}$ IS is a result of complex interactions between environmental and genetic factors. The influence of each gene is expected to be modest. However, it is possible that the tremendous impact of acquired risk factors on stroke occurrence may obscure or eliminate a possible genetic influence on the disease pathophysiology. APOE $\varepsilon 4$ seems to be the best candidate for studying the interplay between genetic and acquired risk factors.

\section{Conclusion}

This review highlighted the association between APOE function and the development of associated diseases. Increasing evidence has suggested a central role for APOE in modulating processes of neurodegeneration, as described. APOE isoforms differentially regulate $\mathrm{A} \beta$ aggregation and clearance in the brain and have distinct functions in regulating brain lipid transport, glucose metabolism, neuronal signaling, and neuroinflammation. APOE isoforms probably accelerate the rate of disease conversion and progression. Therefore, studying APOE and its function may enable the identification of disease risks, which may allow an earlier identification of individuals with the disease. APOE genotype status might help predict a clinical diagnosis and assess treatment efficacy using tools such as putative AD biomarkers, magnetic resonance imaging scans, and measurements of $\mathrm{A} \beta$. In addition, APOE isoforms have differential roles in maintaining vascular health, which is crucial because vascular pathology is strongly associated not only with $\mathrm{AD}$, but also with others diseases as described above. Determination of the association between APOE and the risk of pathogenesis is a considerable challenge, but it is essential for diagnosis, risk assessment, prevention, and treatment of disease in humans.

\section{Acknowledgment}

This work was supported by the grants from Gachon University Gil Medical Center (grant number 2013-22) and the Korea Health Technology R\&D Project (HI14C3331) through the Korea Health Industry Development Institute (KHIDI), Korea Ministry of Health \& Welfare. 


\section{Disclosure}

The authors report no conflicts of interest in this work.

\section{References}

1. Rall SC Jr, Weisgraber KH, Mahley RW. Human apolipoprotein E. The complete amino acid sequence. J Biol Chem. 1982;257(8): 4171-4178.

2. Mahley RW, Huang Y. Apolipoprotein E: from atherosclerosis to Alzheimer's disease and beyond. Curr Opin Lipidol. 1999; 10(3):207-217.

3. Mahley RW, Rall SC. Apolipoprotein E: far more than a lipid transport protein. Annu Rev Genomics Hum Genet. 2000;1:507-537.

4. Rall SC, Weisgraber KH, Innerarity TL, Mahley RW. Structural basis for receptor binding heterogeneity of apolipoprotein E from type III hyperlipoproteinemic subjects. Proc Natl Acad Sci U S A. 1982; 79(15):4696-4700.

5. Emi M, Wu LL, Robertson MA, et al. Genotyping and sequence analysis of apolipoprotein Eisoforms. Genomics. 1988;3(4):373-379.

6. Utermann G, Hees M, Steinmetz A. Polymorphism of apolipoprotein $\mathrm{E}$ and occurrence of dysbetalipoproteinaemia in man. Nature. 1977;269(5629):604-607.

7. Ehnholm C, Lukka M, Kuusi T, Nikkilä E, Utermann G. Apolipoprotein E polymorphism in the Finnish population: gene frequencies and relation to lipoprotein concentrations. J Lipid Res. 1986;27(3):227-235.

8. Eichner JE, Dunn ST, Perveen G, Thompson DM, Stewart KE, Stroehla BC. Apolipoprotein E polymorphism and cardiovascular disease: a HuGE review. Am J Epidemiol. 2002;155(6):487-495.

9. Nguyen D, Dhanasekaran P, Nickel M, et al. Molecular basis for the differences in lipid and lipoprotein binding properties of human apolipoproteins E3 and E4. Biochemistry. 2010;49(51): 10881-10889.

10. Mahley RW. Apolipoprotein E: cholesterol transport protein with expanding role in cell biology. Science. 1988;240(4852):622-630.

11. Zannis VI, Breslow JL, Utermann G, et al. Proposed nomenclature of apoE isoproteins, apoE genotypes, and phenotypes. $J$ Lipid Res. 1982;23(6):911-914.

12. Zhang $\mathrm{H}, \mathrm{Wu} \mathrm{LM}, \mathrm{Wu}$ J. Cross-talk between apolipoprotein $\mathrm{E}$ and cytokines. Mediators Inflamm. 2011;2011:949072.

13. Dietschy JM, Turley SD. Thematic review series: brain Lipids. Cholesterol metabolism in the central nervous system during early development and in the mature animal. J Lipid Res. 2004;45(8):1375-1397.

14. Saher G, Brügger B, Lappe-Siefke C, et al. High cholesterol level is essential for myelin membrane growth. Nat Neurosci. 2005; 8(4):468-475.

15. Mauch DH, Nägler K, Schumacher S, et al. CNS synaptogenesis promoted by glia-derived cholesterol. Science. 2001;294(5545): 1354-1357.

16. Pfrieger FW. Cholesterol homeostasis and function in neurons of the central nervous system. Cell Mol Life Sci. 2003;60(6):1158-1171.

17. Poirier J, Hess M, May PC, Finch CE. Astrocytic apolipoprotein E mRNA and GFAP mRNA in hippocampus after entorhinal cortex lesioning. Brain Res Mol Brain Res. 1991;11(2):97-106.

18. Bien-Ly N, Gillespie AK, Walker D, Yoon SY, Huang Y. Reducing human apolipoprotein $E$ levels attenuates age-dependent $A \beta$ accumulation in mutant human amyloid precursor protein transgenic mice. J Neurosci. 2012;32(14):4803-4811.

19. Kim J, Jiang H, Park S, et al. Haploinsufficiency of human APOE reduces amyloid deposition in a mouse model of amyloid-beta amyloidosis. J Neurosci. 2011;31(49):18007-18012.

20. Ordovas JM, Litwack-Klein L, Wilson PW, Schaefer MM, Schaefer EJ. Apolipoprotein $\mathrm{E}$ isoform phenotyping methodology and population frequency with identification of apoE1 and apoE5 isoforms. $J$ Lipid Res. 1987;28(4):371-380.

21. Singh PP, Singh M, Mastana SS. APOE distribution in world populations with new data from India and the UK. Ann Hum Biol. 2006; 33(3):279-308.
22. Wetterau JR, Aggerbeck LP, Rall SC, Weisgraber KH. Human apolipoprotein E3 in aqueous solution. I. Evidence for two structural domains. J Biol Chem. 1988;263(13):6240-6248.

23. Chen J, Li Q, Wang J. Topology of human apolipoprotein E3 uniquely regulates its diverse biological functions. Proc Natl Acad Sci U S A. 2011;108(36):14813-14818.

24. Segrest JP, Jones MK, De Loof H, Brouillette CG, Venkatachalapathi YV, Anantharamaiah GM. The amphipathic helix in the exchangeable apolipoproteins: a review of secondary structure and function. $J$ Lipid Res. 1992;33(2):141-166.

25. Westerlund JA, Weisgraber KH. Discrete carboxyl-terminal segments of apolipoprotein E mediate lipoprotein association and protein oligomerization. J Biol Chem. 1993;268(21):15745-15750.

26. Weisgraber KH, Rall SC, Mahley RW. Human E apoprotein heterogeneity. Cysteine-arginine interchanges in the amino acid sequence of the apo-E isoforms. J Biol Chem. 1981;256(17):9077-9083.

27. Papaioannou I, Simons JP, Owen JS. Targeted In Situ Gene Correction of Dysfunctional APOE Alleles to Produce Atheroprotective Plasma ApoE3 Protein. Cardiol Res Pract. 2012;2012:148796.

28. Ezquerra M, Campdelacreu J, Gaig C, et al. Lack of association of APOE and tau polymorphisms with dementia in Parkinson's disease. Neurosci Lett. 2008;448(1):20-23.

29. Federoff M, Jimenez-Rolando B, Nalls MA, Singleton AB. A large study reveals no association between APOE and Parkinson's disease. Neurobiol Dis. 2012;46(2):389-392.

30. Liu CC, Liu CC, Kanekiyo T, Xu H, Bu G. Apolipoprotein Eand Alzheimer disease: risk, mechanisms and therapy. Nat Rev Neurol. 2013;9(2): 106-118.

31. Russo C, Angelini G, Dapino D, et al. Opposite roles of apolipoprotein $\mathrm{E}$ in normal brains and in Alzheimer's disease. Proc Natl Acad Sci U S A. 1998;95(26):15598-15602.

32. Tokuda T, Calero M, Matsubara E, et al. Lipidation of apolipoprotein $\mathrm{E}$ influences its isoform-specific interaction with Alzheimer's amyloid beta peptides. Biochem J. 2000;348 Pt 2:359-365.

33. Manelli AM, Stine WB, Van Eldik LJ, LaDu MJ. ApoE and Abeta1-42 interactions: effects of isoform and conformation on structure and function. J Mol Neurosci. 2004;23(3):235-246.

34. LaDu MJ, Munson GW, Jungbauer L, et al. Preferential interactions between ApoE-containing lipoproteins and $A \beta$ revealed by a detection method that combines size exclusion chromatography with non-reducing gel-shift. Biochim Biophys Acta. 2012;1821(2): 295-302.

35. Lehtinen S, Lehtimäki T, Sisto T, et al. Apolipoprotein E polymorphism, serum lipids, myocardial infarction and severity of angiographically verified coronary artery disease in men and women. Atherosclerosis. 1995;114(1):83-91.

36. Muros M, Rodríguez-Ferrer C. Apolipoprotein E polymorphism influence on lipids, apolipoproteins and $\mathrm{Lp}(\mathrm{a})$ in a Spanish population underexpressing apo E4. Atherosclerosis. 1996;121(1): $13-21$.

37. Ribalta J, Vallvé JC, Girona J, Masana L. Apolipoprotein and apolipoprotein receptor genes, blood lipids and disease. Curr Opin Clin Nutr Metab Care. 2003;6(2):177-187.

38. Alzheimer A. Uber eine eigenartige Erkrankung der Hinrinde (Concerning a novel Disease of the cortex). Allgemeine Zeitschrift for Psychiatrie. 1907;64:146-148. German.

39. Alzheimer's Association. 2013 Alzheimer's disease facts and figures. Alzheimers Dement. 2013;9(2):208-245.

40. Hebert LE, Scherr PA, Bienias JL, Bennett DA, Evans DA. Alzheimer disease in the US population: prevalence estimates using the 2000 census. Arch Neurol. 2003;60(8):1119-1122.

41. Näslund J, Thyberg J, Tjernberg LO, et al. Characterization of stable complexes involving apolipoprotein $\mathrm{E}$ and the amyloid beta peptide in Alzheimer's disease brain. Neuron. 1995;15(1):219-228.

42. Wisniewski T, Frangione B. Apolipoprotein E: a pathological chaperone protein in patients with cerebral and systemic amyloid. Neurosci Lett. 1992;135(2):235-238. 
43. Poirier J, Davignon J, Bouthillier D, Kogan S, Bertrand P, Gauthier S. Apolipoprotein E polymorphism and Alzheimer's disease. Lancet. 1993;342(8873):697-699.

44. Rebeck GW, Reiter JS, Strickland DK, Hyman BT. Apolipoprotein E in sporadic Alzheimer's disease: allelic variation and receptor interactions. Neuron. 1993;11(4):575-580.

45. Strittmatter WJ, Saunders AM, Schmechel D, et al. Apolipoprotein E: high-avidity binding to beta-amyloid and increased frequency of type 4 allele in late-onset familial Alzheimer disease. Proc Natl Acad Sci US A. 1993;90(5):1977-1981.

46. Carrasquillo MM, Zou F, Pankratz VS, et al. Genetic variation in PCDH11X is associated with susceptibility to late-onset Alzheimer's disease. Nat Genet. 2009;41(2):192-198.

47. Li H, Wetten S, Li L, et al.Candidate single-nucleotide polymorphisms from a genomewide association study of Alzheimer disease. Arch Neurol. 2008;65(1):45-53.

48. Reiman EM, Webster JA, Myers AJ, et al. GAB2 alleles modify Alzheimer's risk in APOE epsilon4 carriers. Neuron. 2007;54(5): 713-720.

49. Namba Y, Tomonaga M, Kawasaki H, Otomo E, Ikeda K. Apolipoprotein E immunoreactivity in cerebral amyloid deposits and neurofibrillary tangles in Alzheimer's disease and kuru plaque amyloid in CreutzfeldtJakob disease. Brain Res. 1991;541(1):163-166.

50. Corder EH, Saunders AM, Strittmatter WJ, et al. Gene dose of apolipoprotein E type 4 allele and the risk of Alzheimer's disease in late onset families. Science. 1993;261(5123):921-923.

51. Roses AD. Apolipoprotein E alleles as risk factors in Alzheimer's disease. Annu Rev Med. 1996;47:387-400.

52. Selkoe DJ, Schenk D. Alzheimer's disease: molecular understanding predicts amyloid-based therapeutics. Annu Rev Pharmacol Toxicol. 2003; 43:545-584

53. Bertram L, McQueen MB, Mullin K, Blacker D, Tanzi RE. Systematic meta-analyses of Alzheimer disease genetic association studies: the AlzGene database. Nat Genet. 2007;39(1):17-23.

54. Corder EH, Saunders AM, Risch NJ, et al. Protective effect of apolipoprotein E type 2 allele for late onset Alzheimer disease. Nat Genet. 1994;7(2):180-184.

55. Farrer LA, Cupples LA, Haines JL, et al. Effects of age, sex, and ethnicity on the association between apolipoprotein E genotype and Alzheimer disease. A meta-analysis. APOE and Alzheimer Disease Meta Analysis Consortium. JAMA. 1997;278(16):1349-1356.

56. Hébert R, Brayne C. Epidemiology of vascular dementia. Neuroepidemiology. 1995;14(5):240-257.

57. Jellinger KA. Pathology and pathogenesis of vascular cognitive impairment-a critical update. Front Aging Neurosci. 2013;5:17.

58. Kalaria RN. Comparison between Alzheimer's disease and vascular dementia: implications for treatment. Neurol Res. 2003;25(6):661-664.

59. Laitinen MH, Ngandu T, Rovio S, et al. Fat intake at midlife and risk of dementia and Alzheimer's disease: a population-based study. Dement Geriatr Cogn Disord. 2006;22(1):99-107.

60. Luchsinger JA, Tang MX, Shea S, Mayeux R. Caloric intake and the risk of Alzheimer disease. Arch Neurol. 2002;59(8):1258-1263.

61. Baum L, Lam LCW, Kwok T, et al. Apolipoprotein E $\varepsilon 4$ allele is associated with vascular dementia. Dement Geriatr Cogn Disord. 2006; 22(4):301-305.

62. Chuang YF, Hayden KM, Norton MC, et al. Association between APOE epsilon 4 allele and vascular dementia: The Cache County study. Dement Geriatr Cogn Disord. 2010;29(3):248-253.

63. Liu X, Li L, Liu F, et al. ApoE gene polymorphism and vascular dementia in Chinese population: a meta-analysis. $J$ Neural Transm. 2012;119(3):387-394

64. Yin YW, Li JC, Wang JZ, et al. Association between apolipoprotein E gene polymorphism and the risk of vascular dementia: a metaanalysis. Neurosci Lett. 2012;514(1):6-11.

65. Helisalmi S, Linnaranta K, Lehtovirta M, et al. Apolipoprotein E polymorphism in patients with different neurodegenerative disorders. Neurosci Lett. 1996;205(1):61-64.
66. Kawamata J, Tanaka S, Shimohama S, Ueda K, Kimura J. Apolipoprotein E polymorphism in Japanese patients with Alzheimer's disease or vascular dementia. J Neurol Neurosurg Psychiatry. 1994;57(11): 1414-1416.

67. Prince M, Lovestone S, Cervilla J, et al. The association between APOE and dementia does not seem to be mediated by vascular factors. Neurology. 2000;54(2):397-402.

68. Fuster V, Kelly BB. Promoting Cardiovascular Health in the Developing World: A Critical Challenge to Achieve Global Health. Washington, DC: National Academies Press; 2010.

69. Stengård JH, Weiss KM, Sing CF. An ecological study of association between coronary heart disease mortality rates in men and the relative frequencies of common allelic variations in the gene coding for apolipoprotein E. Hum Genet. 1998;103(2):234-241.

70. Eichner JE, Kuller LH, Orchard TJ, et al. Relation of apolipoprotein E phenotype to myocardial infarction and mortality from coronary artery disease. Am J Cardiol. 1993;71(2):160-165.

71. Stengård JH, Pekkanen J, Sulkava R, Ehnholm C, Erkinjuntti T, Nissinen A. Apolipoprotein E polymorphism, Alzheimer's disease and vascular dementia among elderly Finnish men. Acta Neurol Scand. 1995;92(4):297-298.

72. Schiele F, De Bacquer D, Vincent-Viry M, et al. Apolipoprotein E serum concentration and polymorphism in six European countries: the ApoEurope Project. Atherosclerosis. 2000;152(2): 475-488.

73. Mahley RW, Huang Y, Rall SC Jr. Pathogenesis of type III hyperlipoproteinemia (dysbetalipoproteinemia). Questions, quandaries, and paradoxes. J Lipid Res. 1999;40(11):1933-1149.

74. Mabuchi $\mathrm{H}$, Itoh $\mathrm{H}$, Takeda $\mathrm{M}$, et al. A young type III hyperlipoproteinemic patient associated with apolipoprotein E deficiency. Metabolism. 1989;38(2):115-119.

75. Schaefer EJ, Gregg RE, Ghiselli G, et al. Familial apolipoprotein E deficiency. J Clin Invest. 1986;78(5):1206-1219.

76. Davignon J, Gregg RE, Sing CF. Apolipoprotein E polymorphism and atherosclerosis. Arteriosclerosis. 1988;8(1):1-21.

77. Visser ME, Dallinga-Thie GM, Pinto-Sietsma SJ, Defesche JC, Stroes ES, van der Valk PR. APOE1 mutation in a patient with type III hyperlipoproteinaemia: detailed genetic analysis required. Neth $J$ Med. 2012;70(6):278-280.

78. de Knijff P, van den Maagdenberg AM, Boomsma DI, et al. Variable expression of familial dysbetalipoproteinemia in apolipoprotein E*2 (Lys146 $\rightarrow$ Gln) Allele carriers. J Clin Invest. 1994;94(3): $1252-1262$.

79. Hoffer MJ, Niththyananthan S, Naoumova RP, et al. Apolipoprotein E1-Hammersmith E1 (Lys146Asn; Arg147Trp), due to a dinucleotide substitution, is associated with early manifestation of dominant type III hyperlipoproteinaemia. Atherosclerosis. 1996;124(2):183-189.

80. Hoffmann MM, Scharnagl H, Köster W, Winkler K, Wieland H, März W. Apolipoprotein E1 Baden $(\operatorname{Arg}(180) \rightarrow$ Cys). A new apolipoprotein E variant associated with hypertriglyceridemia. Clin Chim Acta. 2001;303(1-2):41-48.

81. Mann AW, Gregg RE, Ronan R, Fairwell T, Hoeg JM, Brewer HB. Apolipoprotein E-I Harrisburg, a mutation in the receptor binding domain, that is dominant for dysbetalipoproteinemia results in defective ligand-receptor interactions. Clin Res. 1989;37(2):A520.

82. März W, Hoffmann MM, Scharnagl H, et al. Apolipoprotein E2 (Arg136Cys) mutation in the receptor binding domain of apoE is not associated with dominant type hyperlipoproteinemia. $J$ Lipid Res. 1998;39(3):658-669.

83. Rall SC, Weisgraber KH, Innerarity TL, Bersot TP, Mahley RW, Blum CB. Identification of a new structural variant of human apolipoprotein $\mathrm{E}$, E2(Lys 146 leads to Gln), in a type III hyperlipoproteinemic subject with the E3/2 phenotype. J Clin Invest. 1983;72(4):1288-1297.

84. Walden CC, Huff MW, Leiter LA, Connelly PW, Hegele RA. Detection of a new apolipoprotein-E mutation in type III hyperlipidemia using deoxyribonucleic acid restriction isotyping. J Clin Endocrinol Metab. 1994;78(3):699-704. 
85. Weisgraber KH, Rall SC, Innerarity TL, Mahley RW, Kuusi T, Ehnholm C. A novel electrophoretic variant of human apolipoprotein E. Identification and characterization of apolipoprotein E1. J Clin Invest. 1984;73(4):1024-1033.

86. Hughes AJ, Daniel SE, Lees AJ. The clinical features of Parkinson's disease in 100 histologically proven cases. Adv Neurol. 1993;60 595-599

87. Li YJ, Hauser MA, Scott WK, et al. Apolipoprotein E controls the risk and age at onset of Parkinson disease. Neurology. 2004;62(11): 2005-2009.

88. Pulkes T, Papsing C, Mahasirimongkol S, Busabaratana M, Kulkantrakorn K, Tiamkao S. Association between apolipoprotein E genotypes and Parkinson's disease. J Clin Neurosci. 2011; 18(10):1333-1335.

89. Buchanan DD, Silburn PA, Prince JA, Mellick GD. Association of APOE with Parkinson disease age-at-onset in women. Neurosci Lett 2007;411(3):185-188.

90. Kurz MW, Dekomien G, Nilsen OB, Larsen JP, Aarsland D, Alves G. APOE alleles in Parkinson disease and their relationship to cognitive decline: a population-based, longitudinal study. J Geriatr Psychiatry Neurol. 2009;22(3):166-170.

91. Ryu HG, Kwon OD. Apolipoprotein E epsilon 4 allele is not associated with age at onset or MMSE of Parkinson's disease in a Korean study. Parkinsonism Relat Disord. 2010;16(9):615-617.

92. HarhangiBS, de RijkMC, van Duijn CM, Van Broeckhoven C,Hofman A, Breteler MM. APOE and the risk of PD with or without dementia in a population-based study. Neurology. 2000;54(6):1272-1276.

93. Huang X, Chen PC, Poole C. APOE-[epsilon]2 allele associated with higher pevalence of sporadic Parkinson disease. Neurology. 2004 62(12):2198-2202.

94. Gulliford MC, Charlton J. Is relative mortality of type 2 diabetes mellitus decreasing? Am J Epidemiol. 2009;169(4):455-461.

95. King H, Aubert RE, Herman WH. Global burden of diabetes, 1995 2025: prevalence, numerical estimates, and projections. Diabetes Care 1998;21(9):1414-1431.

96. Ripsin CM, Kang H, Urban RJ. Management of blood glucose in type 2 diabetes mellitus. Am Fam Physician. 2009;79(1):29-36.

97. Risérus U, Willett WC, Hu FB. Dietary fats and prevention of type 2 diabetes. Prog Lipid Res. 2009;48(1):44-51.

98. Stewart R, Liolitsa D. Type 2 diabetes mellitus, cognitive impairment and dementia. Diabet Med. 1999;16(2):93-112.

99. Li L, Hölscher C. Common pathological processes in Alzheimer disease and type 2 diabetes: a review. Brain Res Rev. 2007;56(2) 384-402.

100. Greenow K, Pearce NJ, Ramji DP. The key role of apolipoprotein E in atherosclerosis. J Mol Med (Berl). 2005;83(5):329-342.

101. Guan J, Zhao HL, Baum L, et al. Apolipoprotein E polymorphism and expression in type 2 diabetic patients with nephropathy: clinicopathological correlation. Nephrol Dial Transplant 2009;24(6):1889-1895.

102. Shen HL, Liu LM, Xiang KS, et al. Relationship between ApoE gene polymorphism and type 2 diabetes mellitus with its nephropathy in Chinese. Chin J Diabetes. 2002;10:4-6. Chinese.

103. Xiang Q, Wu YB, Song DP, et al. The study of the association of apolipoprotein E (ApoE) gene polymorphism with diabetic nephropathy in type 2 diabetic patients. Chin J Diabetes. 2010;18:185-186. Chinese.

104. Zhang GW, Zhang AZ, Xu ZF. Association study of apolipoprotein E gene polymorphism and type 2 diabetic nephropathy in Chinese population. Zhejiang Clin Med J. 2007;9:735-736.

105. Pan XR, Yang WY, Li GW, Liu J. Prevalence of diabetes and its risk factors in China, 1994. National Diabetes Prevention and Control Cooperative Group. Diabetes Care. 1997;20(11):1664-1669.

106. Ramachandran A, Snehalatha C, Baskar AD, et al. Temporal changes in prevalence of diabetes and impaired glucose tolerance associated with lifestyle transition occurring in the rural population in India. Diabetologia. 2004;47(5):860-865.
107. Yin YW, Qiao L, Sun QQ, et al. Influence of apolipoprotein E gene polymorphism on development of type 2 diabetes mellitus in Chinese Han population: a meta-analysis of 29 studies. Metabolism. 2014;63(4):532-541.

108. Xie YQ, Wang H, Wu YP, Yin DH, Wang ZS, Huang YH. Association of APOE polymorphisms and insulin resistance with TCM syndromes in type 2 diabetes patients with macroangiopathy. Mol Med Rep. 2011;4(6):1219-1223.

109. Xiong Y, Zhou X, Liu SM, et al. The association of apolipoprotein E genotype with type 2 diabetes mellitus. Chin J Microcirc. 2008;18:28-33.

110. Yang XJ, Xiang GD, Ding XH, et al. Relation between coronary heart disease and apolipoprotein E genotype in NIDDM patients in Wuhan. Chin J Endocrinol Metab. 1995;11:206-210.

111. Dore GA, Elias MF, Robbins MA, Elias PK, Nagy Z. Presence of the APOE epsilon4 allele modifies the relationship between type 2 diabetes and cognitive performance: the Maine-Syracuse Study. Diabetologia. 2009;52(12):2551-2560

112. Berer K, Krishnamoorthy G. Microbial view of central nervous system autoimmunity. FEBS Lett. 2014;588(22):4207-4213.

113. Milo R, Kahana E. Multiple sclerosis: geoepidemiology, genetics and the environment. Autoimmun Rev. 2010;9(5):A387-A394.

114. Pericak-Vance MA, Rimmler JB, Haines JL, et al. Investigation of seven proposed regions of linkage in multiple sclerosis: an American and French collaborative study. Neurogenetics. 2004;5(1):45-48.

115. Sawcer S, Maranian M, Setakis E, et al. A whole genome screen for linkage disequilibrium in multiple sclerosis confirms disease associations with regions previously linked to susceptibility. Brain. 2002;125(Pt 6):1337-1347.

116. Parmenter BA, Shucard JL, Benedict RH, Shucard DW. Working memory deficits in multiple sclerosis: comparison between the n-back task and the Paced Auditory Serial Addition Test. J Int Neuropsychol Soc. 2006;12(5):677-687.

117. Savettieri G, Messina D, Andreoli V, et al. Gender-related effect of clinical and genetic variables on the cognitive impairment in multiple sclerosis. J Neurol. 2004;251(10):1208-1214.

118. Pinholt M, Frederiksen JL, Christiansen M. The association between apolipoprotein E and multiple sclerosis. Eur J Neurol. 2006; 13(6):573-580.

119. Shi J, Zhao CB, Vollmer TL, Tyry TM, Kuniyoshi SM. APOE epsilon 4 allele is associated with cognitive impairment in patients with multiple sclerosis. Neurology. 2008;70(3):185-190.

120. van der Walt A, Stankovich J, Bahlo M, et al. Apolipoprotein genotype does not influence MS severity, cognition, or brain atrophy. Neurology. 2009;73(13):1018-1025

121. Oliveri RL, Cittadella R, Sibilia G, et al. APOE and risk of cognitive impairment in multiple sclerosis. Acta Neurol Scand. 1999;100(5): 290-295.

122. Koutsis G, Panas M, Giogkaraki E, et al. APOE epsilon4 is associated with impaired verbal learning in patients with MS. Neurology 2007;68(8):546-549.

123. Lill CM, Liu T, Schjeide BM, et al; ANZgene Consortium. Closing the case of APOE in multiple sclerosis: no association with disease risk in over 29,000 subjects. J Med Genet. 2012;49(9):558-562.

124. Lopez AD, Mathers CD, Ezzati M, Jamison DT, Murray CJ. Global and regional burden of disease and risk factors, 2001: systematic analysis of population health data. Lancet. 2006;367(9524):1747-1757.

125. Feigin VL, Forouzanfar MH, Krishnamurthi R, et al; Global Burden of Diseases, Injuries, and Risk Factors Study 2010 (GBD 2010) and the GBD Stroke Experts Group. Global and regional burden of stroke during 1990-2010: findings from the Global Burden of Disease Study 2010. Lancet. 2014;383(9913):245-254.

126. Wilson PW, Schaefer EJ, Larson MG, Ordovas JM. Apolipoprotein E alleles and risk of coronary disease. A meta-analysis. Arterioscler Thromb Vasc Bioi. 1996;16(10):1250-1255.

127. Luthra K, Prasad K, Kumar P, Dwivedi M, Pandey RM, Das N. Apolipoprotein E gene polymorphism in cerebrovascular disease: a case-control study. Clin Genet. 2002;62(1):39-44. 
128. Peng DQ, Zhao SP, Wang JL. Lipoprotein (a) and apolipoprotein E epsilon 4 as independent risk factors for ischemic stroke. J Cardiovasc Risk. 1999;6(1):1-6.

129. McCarron MO, Delong D, Alberts MJ. APOE genotype as a risk factor for ischemic cerebrovascular disease: a meta-analysis. Neurology. 1999;53(6):1308-1311.

130. Treger I, Froom P, Ring H, Friedman G. Association between apolipoprotein E4 and rehabilitation outcome in hospitalized ischemic stroke patients. Arch Phys Med Rehabil. 2003;84(7):973-976.

131. Paternoster L, Martínez González NA, Lewis S, Sudlow C. Association between apolipoprotein $\mathrm{E}$ genotype and carotid intima-media thickness may suggest a specific effect on large artery atherothrombotic stroke. Stroke. 2008;39:48-54.

132. Smith LC, Pownall HJ, Gotto AM Jr. The plasma lipoproteins: structure and metabolism. Annu Rev Biochem. 1978;47:751-757.

133. Corbo RM, Scacchi R, Mureddu L, Mulas G, Alfano G. Apolipoprotein E polymorphism in Italy investigated in native plasma by a simple polyacrylamide gel isoelectric focusing technique. Comparison with frequency data of other European populations. Ann Hum Genet. 1995;59(Pt 2):197-209.

134. Gerdes LU, Klausen IC, Sihm I, Faergeman O. Apolipoprotein E polymorphism in a Danish population compared to findings in 45 other study populations around the world. Genet Epidemiol. 1992;9(3):155-167.

135. Braeckman L, De Bacquer D, Rosseneu M, De Backer G. Apolipoprotein E polymorphism in middle-aged Belgian men: phenotype distribution and relation to serum lipids and lipoproteins. Atherosclerosis. 1996;120(1-2):67-73.

136. Lucotte G, Loirat F, Hazout S. Pattern of gradient of apolipoprotein E allele *4 frequencies in western Europe. Hum Biol. 1997;69(2): 253-262.

137. Kowalska A, Wiechmann I, Walter H. Genetic variability of apolipoprotein E in a Polish population. Hum Biol. 1998;70(6):1093-1099.

138. Valveny N, Esteban E, Kandil M, Moral P. APO E polymorphism in Spanish and Moroccan populations. Clin Genet. 1997;51(5):354-356.

139. Atadzhanov M, Mwaba MH, Mukomena PN, et al. Frequency of APOE, MTHFR and ACE polymorphisms in the Zambian population. BMC Res Notes. 2014;7:194.

140. Oriá RB, Patrick PD, Oriá MO, et al. ApoE polymorphisms and diarrheal outcomes in Brazilian shanty town children. Braz J Med Biol Res. 2010;43(3):249-256.

141. Zekraoui L, Lagarde JP, Raisonnier A, Gérard N, Aouizérate A, Lucotte G. High frequency of the apolipoprotein E*4 allele in African pygmies and most of the African populations in sub-Saharan Africa. Hum Biol. 1997;69(4):575-581.

142. Sandholzer C, Delport R, Vermaak H, Utermann G. High frequency of the apo epsilon 4 allele in Khoi San from South Africa. Hum Genet. 1995;95(1):46-48.

143. Hallman DM, Boerwinkle E, Saha N, et al. The apolipoprotein E polymorphism: a comparison of allele frequencies and effects in nine populations. Am J Hum Genet. 1991;49(2):338-349.

144. Corbo RM, Scacchi R, Rickards O, Martinez-Labarga C, De Stefano GF. An investigation of human apolipoprotein B and E polymorphisms in two African populations from Ethiopia and Benin. Am J Hum Biol. 1999;11(3):297-304.

145. Ahmed MU, Akhteruzzaman S. Apolipoprotein E (Apo E) gene polymorphism in the Bangladeshi population and its comparison with other Asian populations. J Med Sci. 2006;6(2):203-208.

146. Gajra B, Candlish JK, Saha N, Mak JW, Tay JS. Effect of apolipoprotein E variants on plasma lipids and apolipoproteins in the Orang Asli ('Aborigines') of Malaysia. Hum Hered. 1994;44(4):209-213.

147. Evans AE, Zhang W, Moreel JF, et al. Polymorphisms of the apolipoprotein $\mathrm{B}$ and $\mathrm{E}$ genes and their relationship to plasma lipid variables in healthy Chinese men. Hum Genet. 1993;92(2):191-197.

148. Moon K, Sung SH, Chang YK, et al. [The association between Apolipoprotein E genotype and lipid profiles in healthy woman workers]. J Prev Med Public Health. 2010;43(3):213-221. Korean.
149. Scacchi R, Corbo RM, Rickards O, Mantuano E, Guevara A, De Stefano GF. Apolipoprotein B and E genetic polymorphisms in the Cayapa Indians of Ecuador. Hum Biol. 1997;69(3):375-382.

150. Kamboh MI. Apolipoprotein E polymorphism and susceptibility to Alzheimer's disease. Hum Biol. 1995;67(2):195-215.

151. Crews DE, Kamboh MI, Mancilha-Carvalho JJ, Kottke B. Population genetics of apolipoprotein A-4, E, and H polymorphisms in Yanomami Indians of Northwestern Brazil: associations with lipids, lipoproteins, and carbohydrate metabolism. Hum Biol. 1993;65(2):211-224.

152. van den Maagdenberg AM, Weng W, de Bruijn IH, et al. Characterization of five new mutants in the carboxyl-terminal domain of human apolipoprotein E: no cosegregation with severe hyperlipidemia. Am J Hum Genet. 1993;52(5):937-946.

153. Matsunaga A, Sasaki J, Komatsu T, et al. A novel apolipoprotein E mutation, E2 (Arg25Cys), in lipoprotein glomerulopathy. Kidney Int. $1999 ; 56(2): 421-427$.

154. Vialettes B, Reynier P, Atlan-Gepner C, et al. Dietary fat clearance in type $\mathrm{V}$ hyperlipoproteinaemia secondary to a rare variant of human apolipoprotein E: the apolipoprotein E3 (Arg $136 \rightarrow$ Ser). Br J Nutr. 2000;83(6):615-622.

155. Richard P, de Zulueta MP, Beucler I, De Gennes JL, Cassaigne A, Iron A. Identification of a new apolipoprotein E variant (E2 Arg142 $\rightarrow$ Leu) in type III hyperlipidemia. Atherosclerosis. 1995;112(1):19-28.

156. Oikawa S, Matsunaga A, Saito T, et al. Apolipoprotein E Sendai (arginine $145 \rightarrow$ proline): a new variant associated with lipoprotein glomerulopathy. J Am Soc Nephrol. 1997;8(5):820-823.

157. Okubo M, Aoyama Y, Harada K, et al. A novel apolipoprotein E2 variant, E2Toranomon (Q187E), identified in a type III hyperlipoproteinemia patient with coronary atherosclerosis. Atherosclerosis. 1998;140(1):187-190.

158. Moriyama K, Sasaki J, Takada Y, et al. Characterization of a novel variant of apolipoprotein E, E2 Fukuoka (Arg-224 $\rightarrow$ Gln) in a hyperlipidemic patient with xanthomatosis. Biochim Biophys Acta. 1996;1301(3):185-190.

159. Wardell MR, Rall SC, Brennan SO, et al. Apolipoprotein E2-Dunedin (228 Arg replaced by Cys): an apolipoprotein E2 variant with normal receptor-binding activity. J Lipid Res. 1990;31(3):535-543.

160. Lalazar A, Weisgraber KH, Rall SC Jr, et al. Site-specific mutagenesis of human apolipoprotein E. Receptor binding activity of variants with single amino acid substitutions. J Biol Chem. 1988; 263(8):3542-3545.

161. McLean JW, Elshourbagy NA, Chang DJ, Mahley RW, Taylor JM. Human apolipoprotein E mRNA. cDNA cloning and nucleotide sequencing of a new variant. J Biol Chem . 1984;259(10):6498-6504.

162. Miserez AR, Scharnagl H, Muller PY, et al. Apolipoprotein E3Basel: new insights into a highly conserved protein region. Eur J Clin Invest. 2003;33(8):677-685.

163. Minnich A, Weisgraber KH, Newhouse Y, et al. Identification and characterization of a novel apolipoprotein E variant, apolipoprotein E3' (Arg136 $\rightarrow$ His): association with mild dyslipidemia and double prebeta very low density lipoproteins. J Lipid Res. 1995;36(1):57-66.

164. Wieland H, Funke H, Krieg J, Luley C. ApoE3-Freiburg and apoE4-Freiburg are twon genetic apoE variants which are caused by exchanges of uncharged amino acids and do not appear to be associated with lipid disorders or heart disease. In: Abstract Book of the Ninth International Symposium on Atherosclerosis; Oct 6-11, 1991; Chicago, IL:164.

165. Suehiro T, Yoshida K, Yamano T, Ohno F. Identification and characterization of a new variant of apolipoprotein E (apo E-Kochi). Jpn J Med. 1990;29(6):587-594.

166. Lohse P, Mann WA, Stein EA, Brewer HB. Apolipoprotein E-4Philadelphia (Glu13----Lys, Arg145----Cys). Homozygosity for two rare point mutations in the apolipoprotein E gene combined with severe type III hyperlipoproteinemia. J Biol Chem. 1991;266(16):10479-10484.

167. Kamboh MI, Aston CE, Perez-Tur J, et al. A novel mutation in the apolipoprotein E gene (APOE*4 Pittsburgh) is associated with the risk of late-onset Alzheimer's disease. Neurosci Lett. 1999;263(2-3):129-132. 
168. Orth $\mathrm{M}$, Weng W, Funke H, et al. Effects of a frequent apolipoprotein E isoform, ApoE4Freiburg (Leu28 $\rightarrow$ Pro), on lipoproteins and the prevalence of coronary artery disease in whites. Arterioscler Thromb Vasc Biol. 1999;19(5):1306-1315.

169. Wardell MR, Rall SC, Schaefer EJ, Kane JP, Weisgraber KH. Two apolipoprotein E5 variants illustrate the importance of the position of additional positive charge on receptor-binding activity. J Lipid Res. 1991;32(3):521-528.

170. Mailly F, Xu CF, Xhignesse M, et al. Characterization of a new apolipoprotein E5 variant detected in two French-Canadian subjects. J Lipid Res. 1991;32(4):613-620.

171. Ruzicka V, März W, Russ A, Fisher E, Mondorf W, Gross W. Characterization of the gene for apolipoprotein E5-Frankfurt (Gln81 $\rightarrow$ Lys, Cys $112 \rightarrow \mathrm{Arg}$ ) by polymerase chain reaction, restriction isotyping, and temperature gradient gel electrophoresis. Electrophoresis. 1993;14(10):1032-1037.

172. Feussner G, Dobmeyer J, Gröne HJ, Lohmer S, Wohlfeil S. A 10-bp deletion in the apolipoprotein epsilon gene causing apolipoprotein $\mathrm{E}$ deficiency and severe type III hyperlipoproteinemia. Am J Hum Genet. 1996;58(2):281-291.

173. Yamamura T, Yamamoto A, Sumiyoshi T, Hiramori K, Nishioeda Y, Nambu S. New mutants of apolipoprotein E associated with atherosclerotic diseases but not to type III hyperlipoproteinemia. J Clin Invest. 1984;74(4):1229-1237.

174. Yamauchi K, Tozuka M, Nakabayashi T, et al. Higher avidity binding of apolipoprotein (E-AII) complex than of apolipoprotein E monomer to beta-amyloid. J Neurosci Res. 1999;58(2):301-307.

175. Lohse P, Rader DJ, Brewer HB. Heterozygosity for apolipoprotein E-4Philadelphia (Glu13----Lys, Arg145----Cys) is associated with incomplete dominance of type III hyperlipoproteinemia. $J$ Biol Chem. 1992;267(19):13642-13646.

176. FeussnerG,FeussnerV,Hoffmann MM,LohrmannJ, WielandH, MärzW. Molecular basis of the type III hyperlipoproteinemia in Germany. Hum Mutat. 1998;11(6):417-423.

177. Ando M, Sasaki J, Hua H, et al. A novel 18-amino acid deletion in apolipoprotein E associated with lipoprotein glomerulopathy. Kidney Int. 1999;56(4):1317-1323.

178. Konishi K, Saruta T, Kuramochi S, et al. Association of a novel 3-amino acid deletion mutation of apolipoprotein E (Apo E Tokyo) with lipoprotein glomerulopathy. Nephron. 1999;83(3):214-218.

179. Feussner G, Funke H, Weng W, Assmann G, Lackner KJ, Ziegler R. Severe type III hyperlipoproteinemia associated with unusual apolipoprotein E1 phenotype and epsilon 1/'null' genotype. Eur J Clin Invest. 1992;22(9):599-608.

180. Feussner G, Scharnagl H, Scherbaum C, et al. Apolipoprotein E5 (Glu212 $\rightarrow$ Lys): increased binding to cell surface proteoglycans but decreased uptake and lysosomal degradation in cultured fibroblasts. J Lipid Res. 1996;37(8):1632-1645.
181. Cladaras C,Hadzopoulou-Cladaras M,Felber BK, Pavlakis G, Zannis VI. The molecular basis of a familial apoE deficiency. An acceptor splice site mutation in the third intron of the deficient apoE gene. J Biol Chem. 1987;262(5):2310-2315.

182. Wardell MR, Weisgraber KH, Havekes LM, Rall SC. Apolipoprotein E3-Leiden contains a seven-amino acid insertion that is a tandem repeat of residues 121-127. J Biol Chem. 1989;264(35):21205-21210.

183. Yamanouchi Y, Takano T, Hamaguchi H, Tokunaga K. A novel apolipoprotein E5 variant with a 24-bp insertion causing hyperlipidemia. J Hum Genet. 2001;46(11):633-639.

184. Sanan DA, Weisgraber KH, Russell SJ, et al. Apolipoprotein E associates with beta amyloid peptide of Alzheimer's disease to form novel monofibrils. Isoform apoE4 associates more efficiently than apoE3. J Clin Invest. 1994;94(2):860-869.

185. Shuvaev VV, Siest G. Interaction between human amphipathic apolipoproteins and amyloid beta-peptide: surface plasmon resonance studies. FEBS Lett. 1996;383(1-2):9-12.

186. Yang DS, Smith JD, Zhou Z, Gandy SE, Martins RN. Characterization of the binding of amyloid-beta peptide to cell culture-derived native apolipoprotein E2, E3, and E4 isoforms and to isoforms from human plasma. $J$ Neurochem. 1997;68(2):721-725.

187. Zhou Z, Relkin N, Ghiso J, Smith JD, Gandy S. Human cerebrospinal fluid apolipoprotein $\mathrm{E}$ isoforms are apparently inefficient at complexing with synthetic Alzheimer's amyloid-[beta] peptide (A[beta] 1-40) in vitro. Mol Med. 2002;8(7):376-381.

188. Gylys KH, Fein JA, Tan AM, Cole GM. Apolipoprotein E enhances uptake of soluble but not aggregated amyloid-beta protein into synaptic terminals. J Neurochem. 2003;84(6):1442-1451.

189. Stratman NC, Castle CK, Taylor BM, Epps DE, Melchior GW, CarterDB. Isoform-specific interactions of human apolipoprotein $\mathrm{E}$ to an intermediate conformation of human Alzheimer amyloid-beta peptide. Chem Phys Lipids. 2005;137(1-2):52-61.

190. Petrlova J, Hong HS, Bricarello DA, et al. A differential association of Apolipoprotein $\mathrm{E}$ isoforms with the amyloid- $\beta$ oligomer in solution. Proteins. 2011;79(2):402-416.

191. Tai LM, Bilousova T, Jungbauer L, et al. Levels of soluble apolipoprotein E/amyloid-beta (Abeta) complex are reduced and oligomeric Abeta increased with APOE4 and Alzheimer disease in a transgenic mouse model and human samples. J Biol Chem. 2013;288(8): 5914-5926.
Neuropsychiatric Disease and Treatment

\section{Publish your work in this journal}

Neuropsychiatric Disease and Treatment is an international, peerreviewed journal of clinical therapeutics and pharmacology focusing on concise rapid reporting of clinical or pre-clinical studies on a range of neuropsychiatric and neurological disorders. This journa is indexed on PubMed Central, the 'PsycINFO' database and CAS,

\section{Dovepress}

and is the official journal of The International Neuropsychiatric Association (INA). The manuscript management system is completely online and includes a very quick and fair peer-review system, which is all easy to use. Visit http://www.dovepress.com/testimonials.php to read real quotes from published authors. 